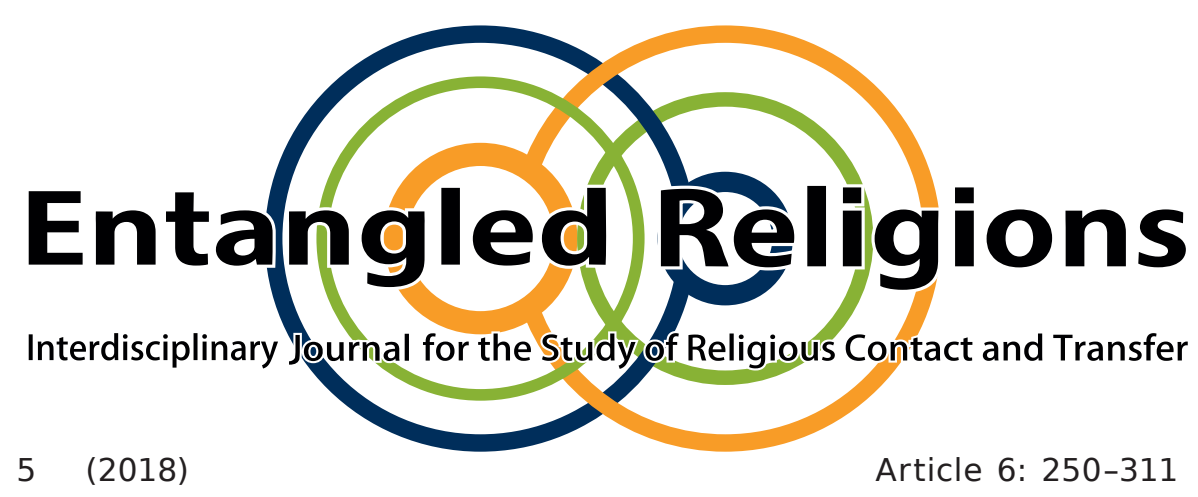

\title{
Linking Khotan and Dūnhuáng: Buddhist Narratives in Text and Image
}

CHRISTOPH ANDERL

Department of Languages and Cultures, Ghent University, Belgium

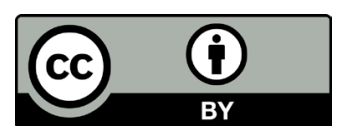

This contribution to Entangled Religions is published under the Creative Commons Attribution 4.0 International Public License (CC BY 4.0 International). The license can be accessed at https://creativecommons.org/licenses/by/4.0/legalcode.

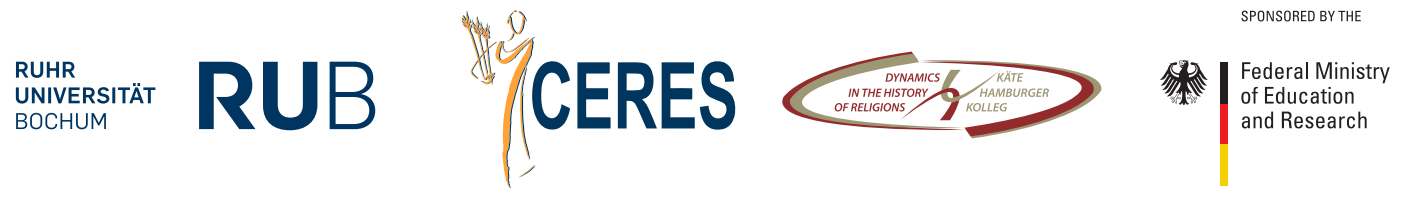




\title{
Linking Khotan and Dūnhuáng: Buddhist Narratives in Text and Image ${ }^{1}$
}

\author{
CHRISTOPH ANDERL \\ Ghent University
}

\begin{abstract}
In the propagation and spread of Buddhism throughout Asia, jātaka and avadāna narratives played a decisive role, both in the form of texts and iconographical representations. In this paper I will focus on another set of narratives which enjoyed great popularity in the Dūnhuáng area during the later Tang and Five Dynasties period, dealing with historical projections concerning the origin and transmission of Buddhism. In this stories, "Auspicious Statues" (ruixiàng 瑞像) play a key role. These "living" statues were thought to have moved from Indian monasteries to Khotan and other regions, serving as agents of the transmission of the Dharma in these areas. Besides reflecting religious key concern during that period, the historical narratives on the spread of Buddhism also give witness to the close diplomatic and family relations between Dunhuang and the Kingdom of Khotan during that period.
\end{abstract}

KEY WORDS Mogao caves; Auspicious Statues; 瑞像; Khotan;

Dunhuang; Buddhist narratives; transmission of Buddhism;

localization of Buddhism; Oxhead Mountain; 牛頭山

1 This paper was presented at the workshop "Ancient Central Asian Networks. Rethinking the Interplay of Religions, Art and Politics across the Tarim Basin (5th-10th century)", organized by Erika Forte with the cooperation of Carmen Meinert and myself. The workshop was held in June 2014 with the funds of the Käte Hamburger Kollege (KHK) "Dynamics in the History of Religions Between Asia and Europe", and hosted at the Center for Religious Studies (CERES) of Ruhr-Universität Bochum (Germany). The workshop proceedings are available as a Special Issue of BuddhistRoad Papers (https://omp.ub.rub. de/index.php/BuddhistRoad/catalog/category/Transfer) edited by Erika Forte.

This article represents the state of research of July 2015. Since then several important publications have appeared, most notably the two monographs Zhāng Xiăogāng 2015 and Jiǎng Jiāhuá 2016. 


\section{Introduction}

In the propagation and spread of Buddhism throughout Asia, narratives played a decisive role, both in the form of texts and iconographical representations. Many of the popular stories are extant in various textual and visual forms, and frequently a complex interplay between these two media can be observed.

After the introduction of Buddhism to China, the accounts and depictions of the selfless acts of the Buddha in his countless former lives (jātaka)during which he accumulated merit sufficient to be reborn as Śākyamuni and gain enlightenment-and the great deeds of other Buddhist heroes described in the avadāna texts enjoyed tremendous popularity. These types of stories initially also played a main role in the transmission of Buddhism to Central Asia and China, judged by the frequency of their translations and extant iconographical representations in Buddhist caves and other sites. However, from the early Táng onwards, one can observe a certain decrease of interest in the depiction of jātakas and avadānas in the Chinese context, ${ }^{2}$ paralleled by the rise of new types of narratives based predominantly on popular Mahāyāna sūtras. From the mid-Táng period onwards, these so-called Sūtra Transformation Tableaux (biànxiàng 變相) became the dominant visual genre in the Mògāo 莫高 caves $^{3}$ of Dūnhuáng 敦煌. As Neil Schmid observes:

2 In the early art of Dūnhuáng, large multi-scenic jātaka tableaux were frequently painted on the main walls of the caves. From mid-Táng times onwards, they usually were merely depicted as detail of the complex Sūtra Transformation Tableaux (similar to the mentioning of only the title or a key event in textual sūtra material, jătakas were then often represented and referenced to with a single scene).

3 In this paper, references to the Dūnhuáng Mògāo caves are abbreviated with D-MG, Yúlín caves with YL. 
Understood as spaces reflecting lay-oriented rituals, the caves participated in the larger, vernacular changes in the medieval religious landscape in China in which transformations in ritual practice and beliefs rendered the divine more accessible to the general populace. Dunhuang caves provide examples of these developments in exceptionally vivid and concrete terms. $(2006,177)^{4}$

However, other sets of narratives also appeared on the walls of the Mògāo caves during the Late Táng and Five Dynasties periods. These 'historical' narratives have so far received somewhat less scholarly attention and mainly deal with the transmission of Buddhism from India to Central Asia and China. Many of the stories focus on historical projections concerning the origin and transmission of Buddhism, and reflect important concerns during the later part of the Táng and Five Dynasties periods. These imaginations on transmission and conversion processes, as evidenced on the murals of Dūnhuáng, coincide with the emergence of sectarian transmission histories in the context of the Tiāntái and Chán schools (this will be shortly discussed below). Several kinds of material, reflected both in manuscripts and in Dūnhuáng wall paintings, are extant and topics include the transmission histories of 'Auspicious Statues' (ruixiàng 瑞像), stories on conversion and the protection of the Dharma, the establishment and localization of Buddhism in China, and the travels and deeds of important monks and missionaries. ${ }^{5}$ In this paper, my focus will be on the Auspicious

4 These 'vernacularization' tendencies are also observable in the development of new genres, such as the Transformation Texts (biànwén 變文) and Sūtra Lecture Texts (jiăngjīng wén 講經文) preserved among the Dūnhuáng manuscripts; in addition, from the tenth century onwards the (semi-)vernacular language was systematically adopted for the dialogue texts of the Chán School.

5 For a rough overview of these topics, see Sūn Xiūshēn 2000, 240-242. In Dūnhuáng, in addition to depictions of the Auspicious Statues and the founding legends of Khotan, 
Statues narratives and the role of Khotan (Yútiān 于闐) in many of the stories. These historical projections on the transmission and development of Buddhism in Khotan do not only indicate religious and iconographical developments, but also actual sociopolitical concerns in the relationship between these two important areas along the Eastern part of the Silk Road. In addition, I will shortly discuss additional evidence concerning aspects of the close Khotan-Dūnhuáng relations, such as founding myths and protective deities.

\section{The Localization of Buddhism in the Tarim Basin and China}

Locations associated with key events in the life of Buddha were of great concern for Chinese pilgrim monks traveling through the Tarim Basin and to Central Asia and India. Many popular narratives were directly related to these locations. Travel accounts would frequently be organized geographically and according to the travel routes of the pilgrims visiting these places as well as those locations they 'heard about' during their journeys. The popularity of stories related to specific regions in Buddha's biography, as evidenced in the manuscripts and depictions of Dūnhuáng, also gives witness to the great influence of these travel diaries and accounts. ${ }^{6}$

many narratives include stories of conversion (frequently including the motive of nāgas, powerful snake-like beings, being converted to Buddhism) or accounts of the great deeds of Buddha, his disciples, or Indian, Central Asian, and Chinese monks.

6 For an excellent study of narratives in the pilgrims' accounts (with a focus on Făxiăn 法 顯), see Deeg 2005. 


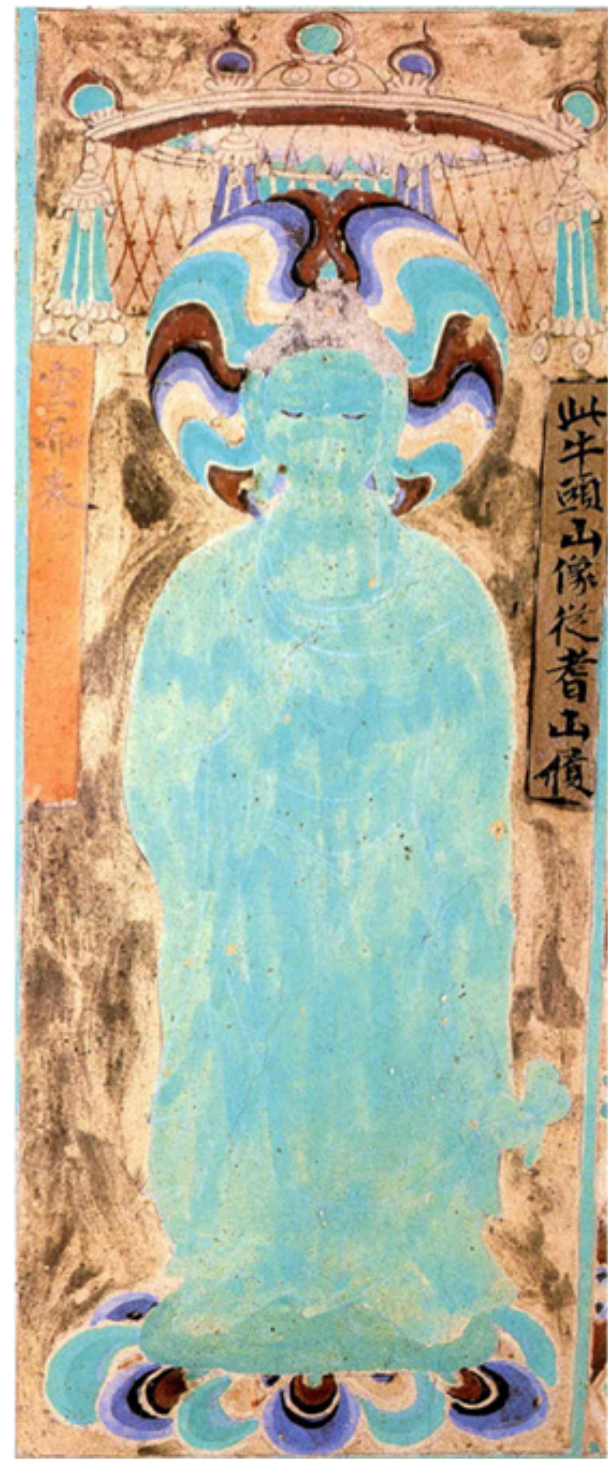

FIGURE 1 'High-speed' transmission to Mt. Niútóu; the caption reads: 此牛頭山像從者山[=闍崛山]履空而來 'This image at Mt. Niútóu (Oxhead Mountain) came from Grdhrakūța ('Vulture Peak'), it came through treading the air.' This describes the transmission process and the emplacement of the deity by means of its 'double' in the form of a statue. As in the case of many other stories, the emphasis on speed/immediacy is noteworthy. Reproduced from Sūn Xiūshēn 2000, 88, ill.69. 
Besides the stories on important key locations in Buddha's career, other narratives directly deal with the movement and 'localization' of Buddhism in the Tarim Basin and China proper. In these stories, statues from India and Gandhāra play a key role and often constitute the very means of the transmission of Buddhism. Famous examples are the localization of Buddhism on Oxhead Mountain (Niútoú shān 牛頭山) or Mañjuśrī’s’ arrival at Wǔtái Mountain (Wǔtái shān 五台山). ${ }^{8}$

Common to these sets of narratives is a preoccupation with movement and localization. The emphasis on 'flying' seems to be especially significant in the transmission between distant locations which could only be reached by considerable efforts and by crossing dangerous mountain ranges and deserts. Indeed, we do not know whether the envoy in the following passage had the luxury of the statues flying abilities in mind when he noted down the following:

7 From mid-Táng onwards, Mt. Wǔtái depictions in Dūnhuáng became more frequent, and were related to the increasing popularity of the Mañjusrī (Wénshū 文殊) cult. D-MG 61 contains a monumental 'map' of the mountain and its numerous temples and monasteries. For a recent study, see Cartelli 2012; for a reproduction of the map, see Sūn Xiūshēn 2000, 202-207; for iconographic compositions of Mañjusrī with the King of Khotan, see, for example, D-MG 220 (reproduced in ibid., 196, ill. 171).

8 The Oxhead Mountain depicted in the Dūnhuáng caves refers to Gośrnga, a mountain in the area of Khotan. As Mauro Maggi has pointed out (personal communication), Gośrnga lit. means 'Oxhorn,' while 'Oxhead' is Gośīrșa. Both names applied to the same hill in the area of Khotan (see also Lévi 1905, 258; Stein 1907, 605-606; Emmerick 1967; Deeg $2005,87)$. Oxhead Mountain depictions developed into an important iconographic genre at the Mògāo and Yúlín caves, and were an ideal medium for visualizing the Buddhist 'sacred geography' of India, Khotan, and China within the same depiction/tableau, as such symbolizing the transmission of Buddhism to China via Khotan (for a short overview of four types of Oxhead Mountain iconography, see Sūn Xiūshēn 2000, 83-100). Oxhead Mountain depictions usually included a depiction of Oxhead Mountain, surrounded by representations of Buddhist narratives from India, Khotan, and China.

Another famous Oxhead Mountain, not related to the translocation of the Auspicious Statues, is situated in today's Jiāngsū 江蘇 Province, south of Nánjīng 南京, and was the location of the assembly of the Chán monk Niútóu Făróng 牛頭法融 (594-657). 
“I shall go as far as Șacū [i.e., Dūnhuáng] making a difficult journey in forty-five days on foot, which with power to fly in the air I had done in one day."

There is something wonderful about someone in the distant past imagining that he could fly from Dunhuang to Khotan. For those who could not fly but went on horseback, the journey from Khotan to Dunhuang took eighteen days. (Hansen 2005, 40) ${ }^{9}$

\section{The Auspicious Statues}

In Dūnhuáng, ruìxiàng 瑞像 or so-called 'Auspicious Statues' depictions prospered between the mid-Táng and the Northern Sòng periods. ${ }^{10}$ As it seems, there is no direct counterpart of this term in Indian material. It is characteristic for the images that they are originally related to specific locations (typically in India and Gandhāra), have specific features and powers, and have been relocated (to Khotan or China) in order to spread the Dharma. As we are informed by captions and manuscript texts, many of them were airborne and flew to the Oxhead Mountain in Khotan. As such, they were the ideal medium of transmission. The background of their appearance in Dūnhuáng is indeed not quite clear but it is certain that the close contacts between Khotan and Dūnhuáng must have

9 Based on an unpublished paper by Prods Oktor Skjærvø, "Perils of Princes and Ambassadors in Tenth-Century Khotan".

10 During the period of Tibetan rule in Dūnhuáng (787-848), Auspicious Statues were depicted rather infrequently (e.g., D-MG 231, 236, 237; however, D-MG 231 contains one of the most complex Auspicious Statues arrangements, including detailed caption texts; see Soymié 1984, 80f.). 
played an important role in this development. ${ }^{11}$ Because of the lack of extant iconographic material on Auspicious Statues in the Khotan area, a direct comparison is not possible; instead, their development must be reconstructed based on the many depictions in Dūnhuáng as well as manuscript material and historical writings. Many narratives concerning these statues seem to be based on accounts of pilgrims visiting Indian and Central Asian sites and reporting on images and their powers at specific locations. However, Dūnhuáng seems to be the earliest location with extant depictions of a variety of these images, often grouped together and embedded in or interacting with other iconographic elements. The extant Auspicious Statues in Dūnhuáng are not the statutes themselves, but painted representations of statues, including buddhas, bodhisattvas, and other Buddhist heroes.

Since the walls of the main rooms of the caves in Dūnhuáng were usually reserved for the large Transformation Tableaux from the early Táng Dynasty onwards, Auspicious Statues were regularly depicted on the walls of the Buddha niches (fókān pō 佛龕坡), ${ }^{12}$ and, from the Late Táng onwards, also on ceilings of the entrance corridors (yǒngdào 甬道) to the caves. At the height of Khotan-Dūnhuáng relations, they were even integrated in the

11 According to Liú Y̌ng $(2010,16)$, the topic of Auspicious Statues (including narratives on buddhas, bodhisattvas, Heavenly Kings, etc.) was originally imported from Khotan. Most of the topics of the stories were based on Indian narratives and iconography, as well as local deities of Khotan. According to the author, the appearance of Auspicious Statues in Tibet can be directly related to Khotan (which came under the control of Tibetans in 791). However, this assumption is problematic since there is no clear archaeological evidence of Auspicious Statues in Khotan. The question of transmission of Buddhist iconographic motifs is notoriously difficult to deal with.

12 The statues of the Buddha niches are frequently not preserved; as such, it is difficult to establish a possible relation between the painted Auspicious Statues depictions and the statues of the niches. 
programmatic Oxhead Mountain depictions of the main walls. ${ }^{13}$ Therefore, the Auspicious Images directly reflect the increasing significance of the diplomatic and family ties between the two locations.

\section{Master Narrative and Mirror Stories}

\section{The Udayana Buddha Image}

The master story concerning Auspicious Statues is based on accounts of kings contemporary to Śākyamuni, Udayana 優填王 and Prasenajit 波斯匿王, according to various sources. The two kings were said to have been early supporters of Buddha's community. Eventually, they were attributed with the creation of the first image of Śăkyamuni. ${ }^{14}$ According to the Auspicious Statues manuscripts, the Udayana story about the creation of the first Buddha statue goes as follows:

13 E.g., Yúlín Cave 33. This complex Oxhead Mountain depiction will be dealt with in a forthcoming study.

14 The Udayana story can be found in the Ekottarāgama sūtra (Zēngyī āhán jīng 增一阿含經, T.2, no.125: 706a), as are two scriptures on image-making, the Fóshuō zuò Fó xíngxiàng jīng 佛說作佛形象經, The Sütra Spoken by the Buddha on Producing Images of the Buddha (T.16, no.692: 788; translator unknown; Tibetan versions of this scripture on the merits of image making are extant), and the extremely short Fóshuō zàolì xíngxiàng fúbào jīng 佛說造立形象福報經 (T.16, no.693), Sūtra Spoken by the Buddha on the Retribution of merit Concerning the Production of Images. However, the main source of the various Auspicious Images narratives seems to be travel accounts, such as the Account of the Eminent Monk Făxiăn (Gāosēng Făxiăn zhuàn 高僧法顯傳, T.51, no.2085) and the Records of the Western Regions of the Great Táng Dynasty (Dàtáng xīyù jì 大唐西域記, T.51, no.2087). I am not aware of any direct Indian parallel to the Udayana story. There is a similar story concerning King Prasenajit ordering the production of a golden image of the Buddha (for an overview of these stories and their variations, see Wenzel 2011, 275f.). 
Śākyamuni Buddha ascended to the $33^{\text {rd }}$ Heaven in order to preach the Dharma to his mother who-because of her untimely death right after the birth of her son-was unable to hear the proclamation of the Dharma after his enlightenment. Buddha did not say farewell to Udayana, and the young King of Kauśāmbī thereupon was overwhelmed with separation anxiety and became fatally ill. One of the foremost disciples of Śākyamuni, Mahā-Maudgalyāyana, ${ }^{15}$ used his supernatural powers and sent artists up to Heaven in order to visit the Buddha. The artists made sketches of Śākyamuni and brought them back, consequently modeling a sandalwood statue of the sage. The King was delighted and venerated the statue, thereby recovering from his illness. Later on, when Śākyamuni returned from Heaven, the statue indeed paid homage to him. ${ }^{16}$ When the Buddha became aware of the effect the statue exercised on the faithful, he instructed Ānanda to promote the veneration of images as an important method for the propagation of the Dharma.

The famous story of the Udayana image is depicted several times in the Mògāo caves from the middle of the Táng Dynasty onwards. In D-MG 231 (mid-Táng), Śākyamuni is depicted dressed in monks' robes and standing on a Lotus pedestal. The caption has the following Chinese text:

15 Maudgalyāyana, one of the foremost ten disciples of the Buddha, was known for his skills in performing miraculous deeds. He is the hero of many Buddhist stories, and in China he enjoyed special popularity as the main protagonist of the Yúlánpén jīng 孟蘭盆經, the 'apocryphal' Ullambana Sütra, which became the basis of the yearly Ghost-festival, still celebrated in East Asia every year, in order to ensure a good rebirth for one's parents. The topic was also expanded on in drama and popular literature. In this text, Mùlián 目 連 (as he is usually referred to in China) shows his great filial devotion to his mother by descending to Hell and trying to save her from the tortures there (finally achieving her rebirth as a dog).

16 The scene of the statue venerating Śăkyamuni is depicted in the mid-Táng caves D-MG 231 and 237, Late Táng cave D-MG 9 (ceiling of entrance tunnel), and the Sòng cave D-MG 454 (entrance tunnel). 


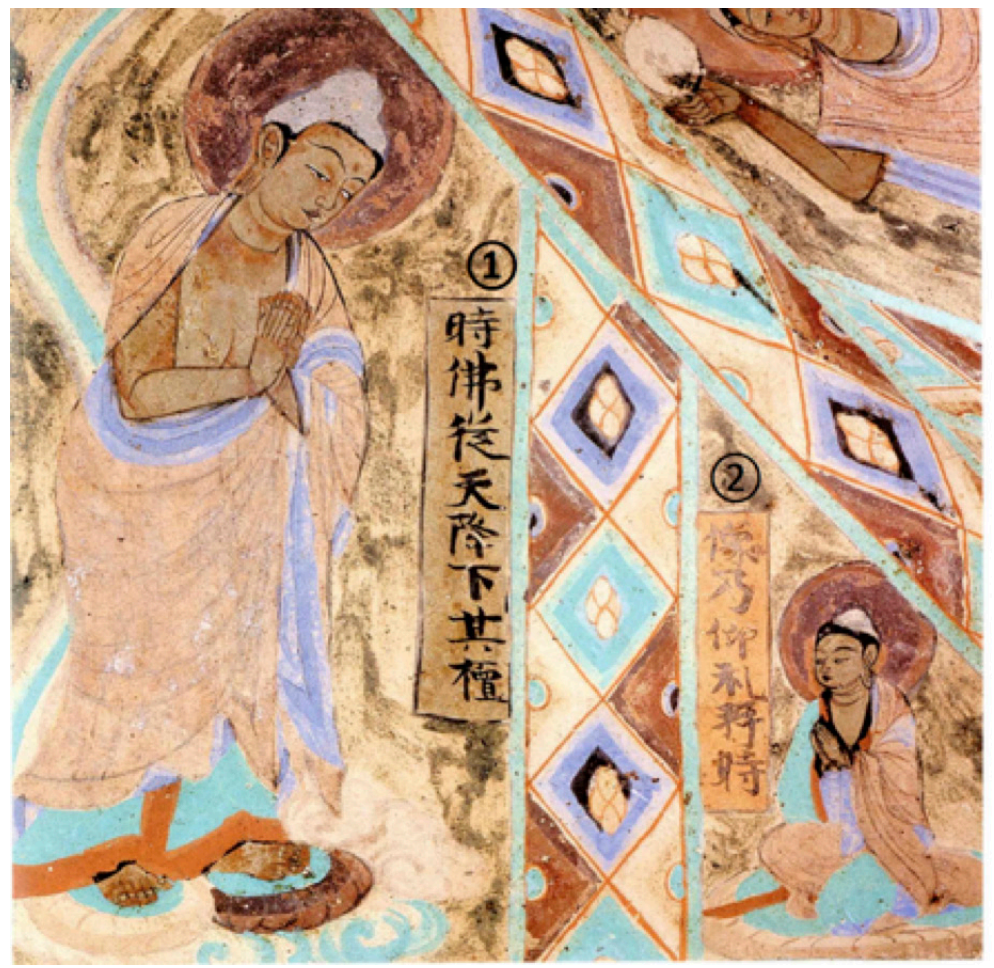

(1)

時

佛

從

天 [1]At the time when

降 Buddha descended

下 from Heaven,

其 the scene when

檀

his sandal wood

[2] statue thereupon welcomes and

(2) worships [him

像

乃

迎

禮

拜

時

FIGURE 2 Śākyamuni greeting his statue when returning from Heaven (adapted from Sūn Xiūshēn 2000, 23, ill.5). The motif (the depiction of which fits well into the corners of slanted Buddha niche ceilings) appears also in D-MG 237 from the mid-Táng period; there, the slanted ceilings of the Western niche are covered by more than 30 Auspicious Statues.

中天竺憍焰彌國寶檀刻瑞像

The Auspicious Image of Kauśāmbi of Middle India, carved on precious sandalwood. ${ }^{17}$

This caption is also recorded in a manuscript text among the Dūnhuáng findings, the Zhū Fó ruixiàng ji 諸佛瑞像記, Records of the Auspicious Buddha Statues (for a short discussion, see below). Another depiction of around

17 If not otherwise indicated, the translations are the author's. 
the same period can be found in D-MG 237 as well as in the Late Táng cave D-MG 9. The Sòng Dynasty cave D-MG 454 contains the scene of Śākyamuni instructing Ānanda on the significance of statues.

The mid-Táng cave D-MG 231 actually shows the interesting motif of Śākyamuni being greeted by his own statue after returning from Heaven; indeed, it indicates that the statue had developed a life of its own, able to act independently of its 'origin.' The statue even engages in a dialogue with the Buddha.

Tracing the path of the traveling Udayana Buddha images in the form of sandalwood statues has not only aroused the interest of modern scholars, ${ }^{18}$ but also exercised great fascination in earlier times. The Zhāntán fóxiàng ji 旃檀佛像記, Record of the Sandalwood Buddha Statue, for example, traces accounts of a statue until the year 1316. The short text is basically divided into three parts. The first part includes a very concise Buddha biography, mentioning his birth (matching the dates with those of the rule of a Zhōu 周 Dynasty king), the rebirth of Buddha's mother in Tușita Heaven, and his abdication of the throne and renouncing home (again providing reference to the dates of the rule of a Zhōu king). Then the text turns to the story of King Udayana, introduced by the remark that Buddha ascended to Heaven in order to repay the kindness of his mother (as such, the important motif of filial piety is also emphasized):

八年辛卯。思報母恩。遂升忉利天。以爲母説法

In the eighth year [of the rule of King Mù 穆 of Zhōu 周, 967 BCE], the xīnmǎo year, he thought of repaying the kindness of his mother and

18 See for example Davis 1997, 1998; Carter 1990; McNair 1994; Wu 1996; Charleux 2009 and 2011 (studying the sandalwood statues in the Mongolian context); Warner 2008 (Tibetan sandalwood images); and McCallum 1998 (Japanese sandalwood images). 
consequently ascended Tușita Heaven in order to expound the Dharma for his mother.

A concise account of the Udayana story is provided, mentioning that both the king and the general populace venerated the statue brought back from Heaven (guówáng chénmín fèng zhī 國王臣民奉之). In the second part, the statue greets the returning Buddha, who makes a prediction about the future of the statue, mentioning its importance for the spread of the Dharma to China:

\section{此像躬迎低頭問訊。佛爲摩頂授記曰。我滅度千年之後。汝從震旦廣利人天。}

This statue welcomed [the Buddha] in person, lowered its head (i.e., bowed) and saluted him. The Buddha touched its forehead and made the following prediction: “1000 years after I have vanished [into nirvāṇa] you will greatly benefit men and gods from [the location of] Zhèndān (i.e., China)."

The third part of the text provides a list of places the statue 'dwelled' in ( $j u \bar{u}$ 居; including the time periods) before it reached its present location of Shèng'ān Monastery 聖安寺. ${ }^{19}$ This text on the Udayana Statue enjoyed great popularity and was consequently translated into Uighur (not extant), and later from Uighur into Tibetan.

19 For an edition of the text, see Kudara 2004, 153; for a map tracing the movement of the statue, see ibid., 154 (including an overview of time periods). 


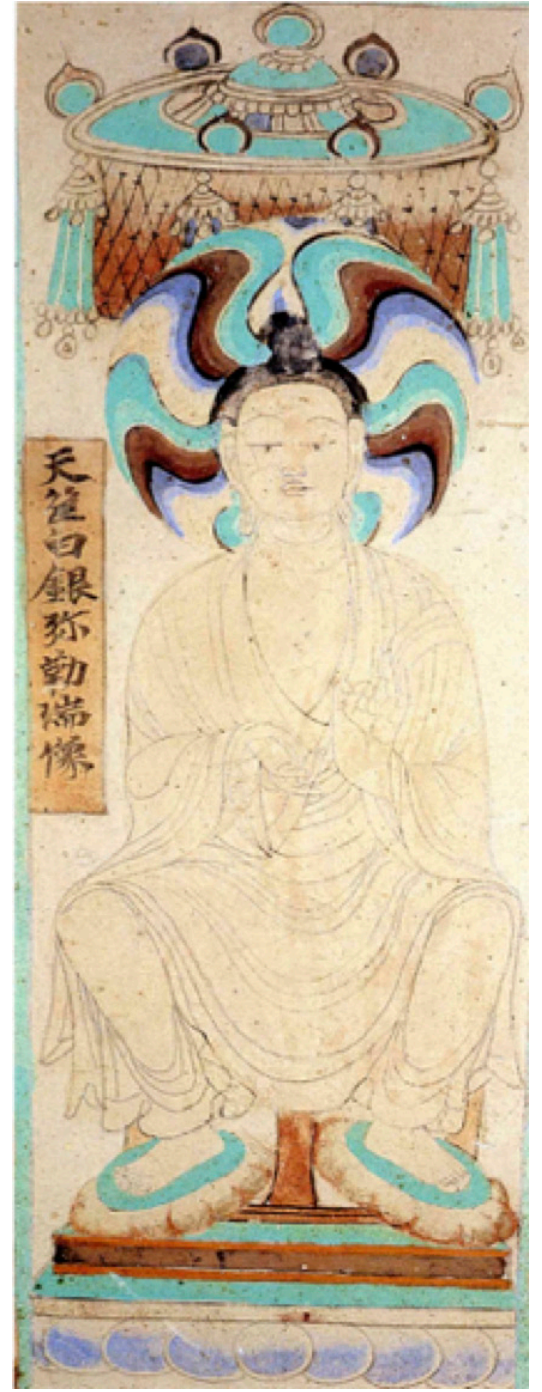

FIGURE 3
Auspicious Statue of Maitreya (D-MG 231, mid-Táng; adapted from Sūn Xiūshēn 2000, 61, ill. 44): 天 笂白銀彌勒瑞相 - The Auspicious Statue of the 'Silver-Maitreya' of India.

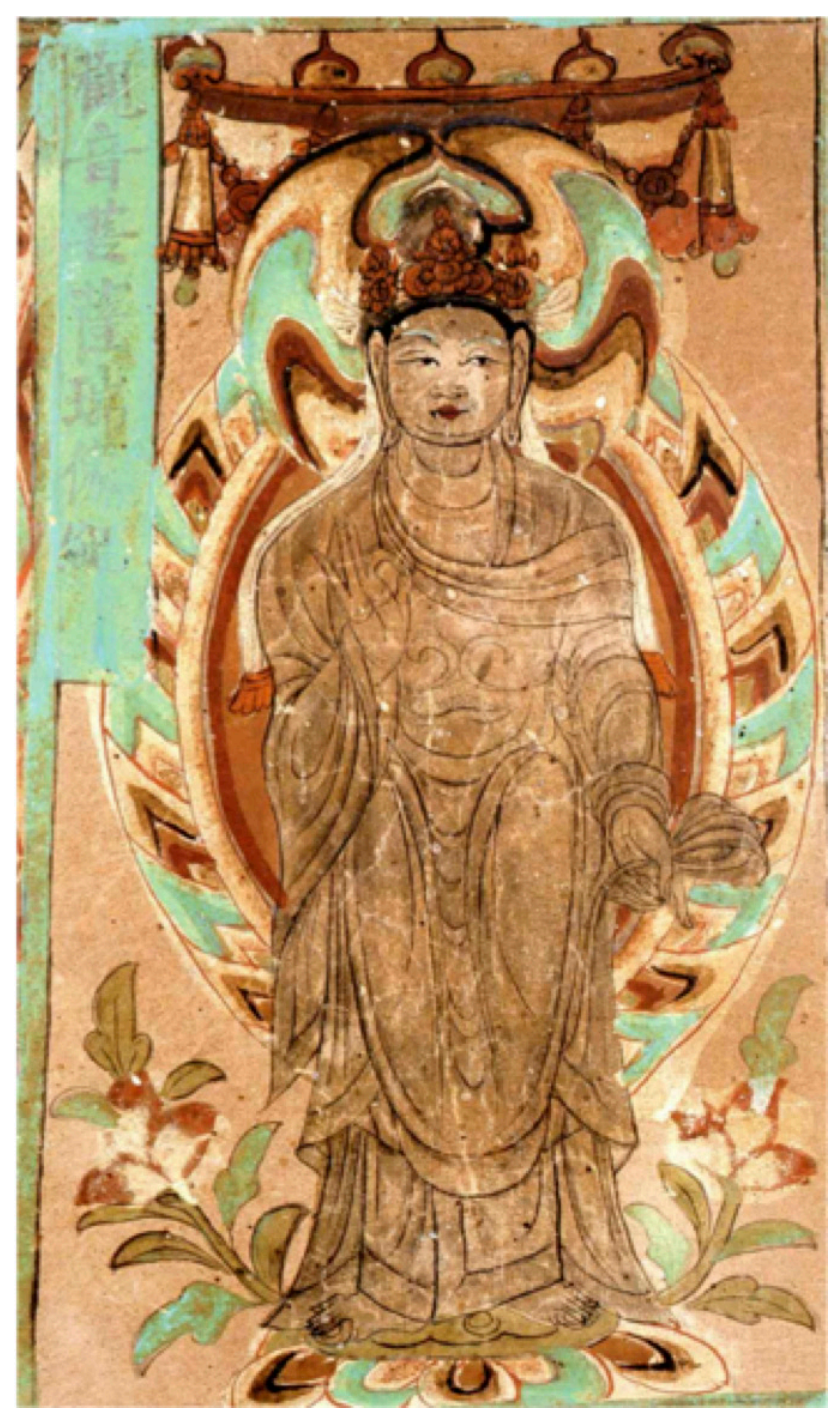

FIGURE 4 Auspicious Statue of Avalokiteśvara (DMG 72, Five Dynasties; adapted from Sūn Xiūshēn 2000，63，ill. 46): 觀音菩薩 瑞相紀 - Record of the Auspicious Statue of Guānyīn (Avalokiteśvara) Bodhisattva (The original statue was supposedly situated in Gandhāra). 


\section{Mirror Stories}

Whereas the 'original' narrative of the first Auspicious Statue became very popular throughout East Asia, there are also several versions in which various narratives are transferred to other 'statue protagonists.' All in all, approximately three dozen different Auspicious Images were depicted in the Mògāo caves. Among these, the story of the Auspicious Statue of Maitreya is of special significance in the context of transmission narratives. ${ }^{20}$ Xuánzàng heard about this story in Udyāna (Wūzhàngnà guó 烏 仗那國) during his travel through northern India (home of the famous monk Fótúchēng 佛圖澄, 232-348 CE). Indeed, Xuánzàng interpreted the transfer of the Maitreya image to the east as the very beginning of the transmission process of Buddhism to the East. In his travel account, he states:

20 There are actually two 'Silver-Maitreya' statues in cave D-MG 231; supposedly, the painting in Dūnhuáng is based on an image of the Indian Mahābodhi Monastery. There is only one exact match with the phrase 白銀爾勒 in CBETA, appearing in the Mílè jīng yóuyì 彌勒經遊意 (T.38, no.1771: 272b5-7); in the text, the very question of the textual origin of a 'Silver Maitreya' is posed!

復有彌勒口教經一卷。若爾合六經耶。問。白銀彌勒出何經。答。一切智光仙人慈心經云。彌勒金色放白銀光 明。黃金校飾。如白銀山。唯有此文・無有白銀色。

Furthermore, there is the Sūtra of the Oral Teachings of Maitreya [?] in one fascicle. Does this correspond to the six sūtras? Question: "From which sūtra is [the term] '(White) Silver Maitreya' extracted from?" Answer: "The Sūtra of the Compassion of All Omniscient Luminous Sages [probably referring to the Yīqiè zhì guāngmíng xiánrén cíxīn yīnyuán bù shí ròu jīng 切智光明仙人慈心因緣不食肉經 Sūtra on the Omniscient Luminous Sages Who Possess the Causes and Conditions of Compassion in Not Eating Meat, T.3, no.183] says: 'The golden color of Maitreya emits a (white) silver light. The yellow golden ornament is like a mountain of white silver. There is this text only. It does not contain [reference to] "color of white silver.'" I am not quite sure whether I understand this passage properly. Probably, the point is that 'Silver-Maitreya' is a misleading name, since the statue is of golden color, and only the light it emits is perceived as silver-colored. As such, the author of the above text emphasizes that there is no textual basis for 'color of white silver' (白銀 色) with reference to Maitreya. 
自有此像法流東派

From when there was this statue (i.e., since the existence of this statue), the Dharma emanated throughout the East. (T.51, no.2087 Dàtáng xīyù jì 大唐西域記, 884b15)

\title{
Dūnhuáng Manuscripts on Auspicious Statues
}

\author{
Among the extant manuscript findings in Dūnhuáng, there are texts \\ directly related to the Auspicious Statues in the Mògāo caves, entitled \\ Zhū Fó ruixiàng jì 諸佛瑞像記, Records of the Auspicious Statues of the \\ Buddhas (short: Records). ${ }^{22}$ These actually appear to be a collection of \\ short records on the various statues, sometimes as short as the caption
}

21 Of course, a golden Buddha image also plays a key role in another important transmission story, describing the 'initial transmission' of Buddhism to China at the time of the Hàn Emperor Míng. The legend is recorded in a collection of Miracle Tales, the Míngxiáng ji 冥祥記, written during the latter part of the fifth century by Wáng Yăn 王琰. The Emperor had a dream about a golden image; an envoy was sent to the West to fetch the statue and place it in the White Horse Temple, Báimă sì 白馬寺. The story of the beginning of Buddhism in China was incorporated in numerous historiographical texts and Chinese Vinaya commentaries.

22 I interpret zhū 諸 as plural marker here rather than meaning 'all.' The longest version is preserved on ms. Stein 2113; other manuscripts on Auspicious States include mss. Pelliot 3033 verso, Pelliot 3352, and Stein 5659. For a critical edition and a very useful annotated translation of sections of the manuscripts, see Soymié 1984. For a recent edition of the manuscripts and a comparison with Dūnhuáng Mògāo caption texts, see Zhāng 2012. Stein 2113 and Stein 5659 were also digitized and critically edited in the Ghent Database of Medieval Chinese Texts (public version forthcoming). 
texts attached to many Dūnhuáng paintings of the statues, occasionally with a short summary of the story or stating some features of the statues. The statues described in the various manuscripts overlap, but there are differences concerning phrasing and descriptions as well as the selection of statues listed. Since iconographical representations of all statues listed in the manuscripts are extant in the Mògāo caves in Dūnhuáng, it is very likely that the records were fabricated by visitors of the caves (or maybe even constituted some kind of manual for the painters of the statues). The extant copies of the manuscripts also postdate the appearance of the Auspicious Statues theme in Dūnhuáng; as such, this order of causality is more likely than the assumption that the captions were produced based on these manuscript texts. In addition, the manuscripts often use the technical term shí 時 'time of > scene,' referring to specific moments of the narratives depicted in the caves. In a recent study, Zhāng Xiăogāng (2012) systematically compared the manuscripts with extant caption texts of the Mògāo caves (See the comments on the Table below).

Since many of the Auspicious Statues as depicted in the caves hinted at 'new' narratives, without established features at the time when they were introduced as new iconographical elements of the caves, it might have been especially important to explicitly identify them through the addition of text (of course, there is an abundance of descriptive cartouches on a variety of Mògāo paintings). In the manuscripts on Auspicious Statues, we also find notes on basic features of the statues, as recorded on Stein 2113, for example. 


\section{Khotan as "Landing Sites" of Indian Buddhist Statues}

In the manuscripts, the stories with Khotan as destination of the flying statues receive special attention, and many images are said to have moved there from a location in India. In many instances, the motion through the air is mentioned. The short passage below (III. 5) reads as follows:

\section{釋迦牟尼佛從舎衛國騰空於固城住}

Śākyamuni was soaring through the air from Śrāvastī and settled at Khotan.

Illustration 6 shows a passage of the manuscript including a short narration of the master story, preceded by another passage, describing a ritual in which the Khotanese King is bathing an Auspicious Statue. ${ }^{23}$

于闐王河浴佛瑞像。身丈餘, 仗錫持鉢。畫形而立。/其像赤體立/

佛在天,叉王 $[=$ 優填王 $]$ 思欲見, 乃 / 令 /目健 (犍) 連曰: 三十二匠往來天圖佛, 令匠取各 一相, 非[=飛?]從降下。24

其檀乃迎本形禮拜 / 其像乘雲下來 /

23 It is also noteworthy that the short descriptions are separated from each other by markers in the form of ' $"$ '.

24 I have interpreted 非 'is not' as phonetic loan for 飛 'to fly;' otherwise the passage does not make much sense. 

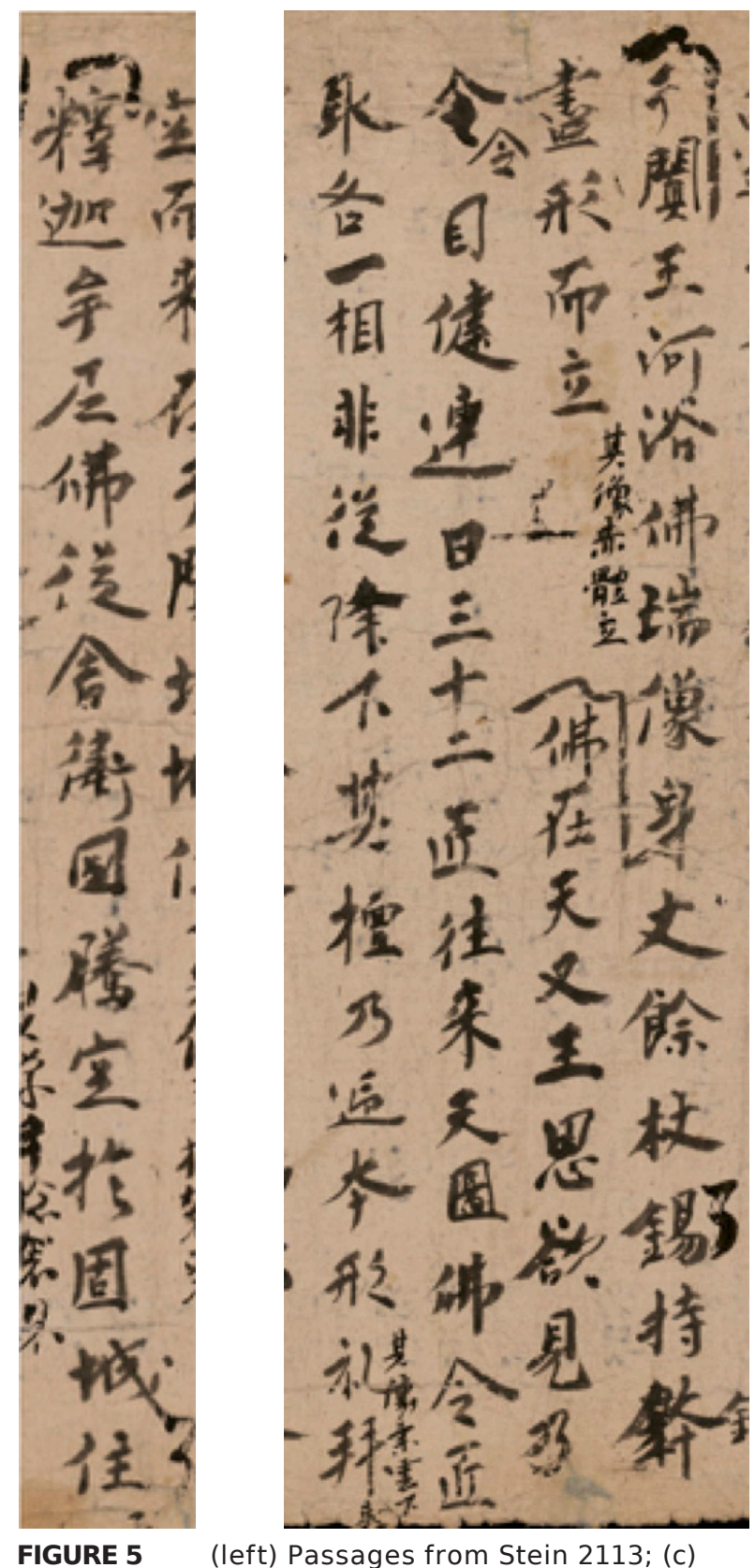

(left) Passages from Stein 2113; (c) The British Library.

FIGURE 6 (right) Passages from Stein 2113; (c) The British Library. 
The King of Khotan is bathing the Auspicious Statue of the Buddha. Its size is more than one zhàng. [The Buddha holds] a monk's staff and a [alms'] bowl. He is depicted standing. /The statue is naked and standing up./ 25

When Buddha was in Heaven, King Udayana wished to see him. He therefore ordered Mùlián, saying: 32 craftsmen [should] go to Heaven and make a drawing of the Buddha. He ordered each craftsman to fetch an image, and to descend flying. The sandalwood [Statue] thereupon met its original form (i.e., Śākyamuni in person) and bowed [to him]. /This statue [is depicted] descending by riding a cloud./

\section{Khotan as a Center of Buddhism}

The earliest reports of Khotan as a Buddhist center were made by the famous pilgrim Fǎxiǎn 法顯 in 400 (Mair/Skjærvø 2011). However, as early as 282 the Chinese monk Zhū Shìxíng 朱士行 stayed in Khotan for an extended period, searching for a Prajñāpāramitā ('Perfection of Wisdom') text, finally sending the Pañcaviṃśatisāhasrikā back to China (see also Deeg 2005, 53; Zürcher 1972, 61-63). According to him, at that time Khotan was dominated by 'Hīnayānists,' followers of the 'Small Vehicle,' contrary to the report of Făxiăn about 100 years later, emphasizing the important role of Mahāyāna there. Khotanese monks were active in the translation of important sūtras into Chinese, and Chinese monks frequently visited Khotan in order to obtain Sanskrit originals as the basis for their translations. Furthermore, the famous Sütra of the Wise and Foolish (445) is said to have been originally

25 A tentative punctuation is added; ' $/$ ' indicate the sections which are written in small characters, usually providing information on special iconographic features of the statues. 
heard by Chinese pilgrims in Khotan when Khotanese monks proclaimed it. ${ }^{26} \mathrm{~A}$ scripture on the merits of the fabrication of Buddhist images was brought to Luòyáng 洛陽 and translated by the Khotanese monk Devaprajñā (Kumamoto 2012, 144). Another Khotanese monk, Śikșānanda, translated the important Avataṃsaka and the Lańkāvatāra sūtras. In the seventh century, Khotan also became a center of dhāraṇis (Buddhist spells) and was probably a major source for their transmission to China. ${ }^{27}$

Among the historiographical narratives depicted in Dūnhuáng, Khotan plays an important role, emphasizing its significance for the spread of Buddhism to the East. It is not only the destination of Auspicious Statues traveling through the air, carrying with them the Buddha-Dharma; additionally, depictions of Khotanese Buddhist legends and its protective deities were very popular iconographic themes in the Mògāo caves. These narratives are not only found in Dūnhuáng wall paintings and manuscripts but also in Tibetan texts ${ }^{28}$ and, to a certain degree, in archeological remains of Khotan itself.

There is also evidence that Khotan by no means regarded itself as 'periphery' in terms of Buddhist activities. On the contrary, in addition to being one of the most important commercial centers along the Silk Road (renowned for the best-quality jade in the world), the area was of great significance for the dissemination (and sometimes also compilation and creation) of Mahāyāna scriptures, and was a center of Buddhist literary activity. Indeed, an important feature of Khotan's Buddhist identity was

26 For a very good study on the textual history of the work, see Mair 2012.

27 For an exhaustive list of Buddhists texts from Khotan, see Kumamoto 2012, 147-149, while Maggi 2009 provides a recent study on Khotanese literature.

28 For a Tibetan text of the tenth century (Nub Sangyé Yeshé: Bsam gtan mig sgron, 5-6), see van Schaik 2013, 1. On Tibetan sources on Buddhist Khotan, see Thomas 1935, Emmerick 1967, and Uray 1979. On texts produced by Khotanese at the court of Shāzhōu 沙洲 (Dūnhuáng), see Skjærvø 2012. 
the eventual claim that the Buddha visited the place in person; ${ }^{29}$ for pious believers, this story catapulted Khotan to one of the original locations in the biography of Buddha. In this story, too, movement through air plays an important role:

\begin{abstract}
These legends do indeed tell of the Buddha visiting Khotan. In one version, he flies over from Vulture's Peak to hover above the lake that covered Khotan in ancient times, before descending to rest upon a lotus throne in the middle of the lake. Other legends also brought to Khotan the bodhisattva Avalokiteśvara and the protector deity Vaiśravaṇa. Reimagining themselves as the centre of their religious world became a surprisingly consistent feature of Khotanese culture (Van Schaik 2013, 2). ${ }^{30}$
\end{abstract}

Below, there is a list of some of the Auspicious Statues, many of which moved from India to Khotan (based on information in the manuscripts and captions texts of the Mògāo caves). ${ }^{31}$

29 For a thorough study of the founding legends of Khotan, see Deeg 2016, 114-139.

30 For an interesting discussion of pre- and post-Buddhist conceptions of self-identity in Tibetan historiography, see Van Schaik 2013, 4f. These include self-descriptions as 'barbarians' or 'demons' before the conversion to Buddhism; by contrast, after the conversion, the civilizing effect of Buddhism is emphasized and eventually crowned by the appearance of a Tibetan Bodhisattva king (8): "The story involves the visit of two Khotanese monks to Tibet. The monks hope to see Avalokiteśvara face to face, and have been told that they may do so by travelling to Tibet and looking upon Songtsen Gampo, who is in fact Avalokiteśvara in person [...]."

More generally on the important role of Central Asia in the development of Buddhism, see Davidson 2002.

31 The most elaborate cave inscriptions can be found in D-MG 231 (dating from the period of Tibetan rule over Dūnhuáng); cf. Somyié 1984, 80-81 for an edition of the caption text. 


\begin{tabular}{|c|c|c|c|}
\hline $\begin{array}{l}\text { AUSPICIOUS STAT- } \\
\text { UE/DEITIES }\end{array}$ & MOVED FROM & $\begin{array}{l}\text { MOVED TO/ } \\
\text { RESIDES IN }\end{array}$ & SOURCES/REMARKS \\
\hline \multicolumn{4}{|l|}{ ŚĀKYAMUNI BUDDHA } \\
\hline $\begin{array}{l}\text { 釋迦牟尼佛 } \\
\text { Śākyamuni Buddha }\end{array}$ & $\begin{array}{l}\text { 靈鷲山 } \\
\text { Gṛhrakūța- } \\
\text { parvata “Vul- } \\
\text { ture Peak" }\end{array}$ & $\begin{array}{l}\text { 牛頭山 } \\
\text { Oxhead Moun- } \\
\text { tain }\end{array}$ & $\begin{array}{l}\text { S.2113v1-2: 釋迦牟尼佛從靈鷲山向牛頭 } \\
\text { 山說法來 Śākyamuni Buddha came } \\
\text { from Grdhrakūța-parvata to Ox- } \\
\text { head Mountain in order to proclaim } \\
\text { the Dharma. } \\
\text { D-MG } 231 \text { (south): right:此牛頭山像從 } \\
\text { 者山履left:空而來 } \\
\text { [Oxhead Mountain Tableaux in } \\
\text { Dūnhuáng: D-MG 9, 340,454; YL } \\
\text { 33] }\end{array}$ \\
\hline $\begin{array}{l}\text { 此像 (S.2114, P.3033) } \\
\text { “This statue" } \\
\text { 憍賞彌國佛 (P.3352) } \\
\text { “The Buddha of } \\
\text { the Country of } \\
\text { Kauśāmbi" }\end{array}$ & $\begin{array}{l}\text { 憍賞彌國 } \\
\text { Country of } \\
\text { Kauśāmbi }\end{array}$ & $\begin{array}{l}\text { 于闐東媲摩 } \\
\text { 城 (S.2114, } \\
\text { P.3033) } \\
\text { Phema* east of } \\
\text { Khotan } \\
\text { 于闐 (P.3352) } \\
\text { Khotan }\end{array}$ & $\begin{array}{l}\text { S.2113v11-12: 此像從憍賞彌國飛往于闐 } \\
\text { 東媲摩城今見在 Thus statue flew from } \\
\text { the country of Kauśāmbi to city of } \\
\text { Phema in the east of Khotan where it } \\
\text { is present today } \\
\text { P.3033v8-9: 此像從憍賞彌國飛往于闐東 } \\
\text { 媲摩城中今見在殊靈瑞 } \\
\text { P.3352r9: 憍賞彌國佛來往[=住]于闐 } \\
\text { S.5659r9: 憍賞彌國佛來住于闐國 } \\
\text { D-MG 231 (south): right: 于闐媲摩城 } \\
\text { 中琱檀瑞像 } \\
\text { D-MG 76 }\end{array}$ \\
\hline $\begin{array}{l}\text { 釋迦牟尼佛真容白檀 } \\
\text { 身 The White sandal } \\
\text { wood image created } \\
\text { face-to-face with (lit. } \\
\text { “true countenance") } \\
\text { Śākyamuni Buddha }\end{array}$ & \begin{tabular}{|l} 
國王舍城 \\
Rājagrha
\end{tabular} & $\begin{array}{l}\text { 于闐海眼寺 } \\
\text { Ocean Eye } \\
\text { Monastery of } \\
\text { Khotan }\end{array}$ & 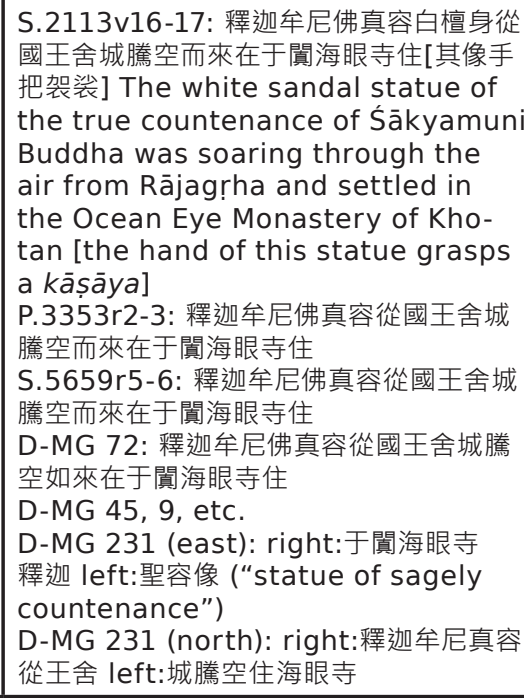 \\
\hline $\begin{array}{l}\text { 釋迦牟尼佛真容白檀香 } \\
\text { 為身 } \\
\text { The true counte- } \\
\text { nance of the Bud- } \\
\text { dha Śākyamuni made } \\
\text { of white sandalwood } \\
\text { (lit. white sandal- } \\
\text { wood being its body) }\end{array}$ & \begin{tabular}{|l} 
漢國 \\
Country of Hàn
\end{tabular} & $\begin{array}{l}\text { 于闐坎城 } \\
\text { Kânchéng of } \\
\text { Khotan (= Phe- } \\
\text { ma?) }\end{array}$ & $\begin{array}{l}\text { S.2113v18-19: 釋迦牟尼佛真容白檀香** } \\
\text { 為身從漢國騰空而來在于闐坎城住[下其 } \\
\text { 像手把袈裟] The true countenance } \\
\text { of the Buddha Śākyamuni made of } \\
\text { white sandalwood soared through } \\
\text { the air form the Country of Hàn } \\
\text { and came to settle at Kănchéng } \\
\text { [below, the statue's hand grasps a } \\
\text { kāșāya] }\end{array}$ \\
\hline
\end{tabular}




\begin{tabular}{|c|c|c|c|}
\hline $\begin{array}{l}\text { AUSPICIOUS STAT- } \\
\text { UE/DEITIES }\end{array}$ & MOVED FROM & $\begin{array}{l}\text { MOVED TO/ } \\
\text { RESIDES IN } \\
\end{array}$ & SOURCES/REMARKS \\
\hline $\begin{array}{l}\text { 釋迦牟尼佛 } \\
\text { Sāakyamuni Buddha }\end{array}$ & $\begin{array}{l}\text { 舍衛國 } \\
\text { Śrāvasti }\end{array}$ & $\begin{array}{l}\text { 固城 } \\
\text { “Old City" [of } \\
\text { Khotan] }\end{array}$ & $\begin{array}{l}\text { S.2113v20: 釋迦牟尼佛從舍衛國 } \\
\text { 騰空於固城住 } \\
\text { [D-MG 231: right:于闐古城瑞像left:?] }\end{array}$ \\
\hline $\begin{array}{l}\text { 釋迦牟尼 } \\
\text { Saākyamuni }\end{array}$ & $\begin{array}{l}\text { 舍衛國 } \\
\text { Śrāvasti }\end{array}$ & $\begin{array}{l}\text { 于闐國城 } \\
\text { City of Khotan }\end{array}$ & $\begin{array}{l}\text { S.2113v31-32: 釋迦牟尼亦從舍衛國 } \\
\text { 騰空同來在于闐國城住[手把袈㳖] } \\
\text { Sākyamuni also soared through } \\
\text { the air from Śrāvasti and came to } \\
\text { settle in City of Khotan [the hand } \\
\text { grasps a kāșāya] } \\
\text { D-MG } 72 \text { (caption nearly identical) }\end{array}$ \\
\hline $\begin{array}{l}\text { 徽波陀佛 } \\
\text { (not identified Bud- } \\
\text { dha) }\end{array}$ & $\begin{array}{l}\text { 舍衛國 } \\
\text { Śrāvasti }\end{array}$ & $\begin{array}{l}\text { 于闐城 } \\
\text { City of Khotan }\end{array}$ & $\begin{array}{l}\text { S.2113v32-34: 徽波陀佛從舍衛國 } \\
\text { 住騰空而同來在于闐城住城人欽敬不 } \\
\text { 可思議[其下像側] Huībōtuó Bud- } \\
\text { dha soared through the air from } \\
\text { Śrāvasti and came together to set- } \\
\text { tle in the City of Khotan; the rever- } \\
\text { ence of the inhabitants of the city } \\
\text { was inconceivable [below, the stat- } \\
\text { ue is slanted (?)] } \\
\text { D-MG } 76 \text { (partly damaged; extant } \\
\text { text identical) }\end{array}$ \\
\hline \multicolumn{4}{|l|}{ OTHER BUDDHAS } \\
\hline $\begin{array}{l}\text { 迦葉佛 } \\
\text { Kāśyapa Buddha (i.e.., } \\
\text { the Buddha prior to } \\
\text { Śākyamuni) }\end{array}$ & $\begin{array}{l}\text { 舍衛國 } \\
\text { Śrāvasti }\end{array}$ & $\begin{array}{l}\text { 于闐 } \\
\text { Khotan }\end{array}$ & $\begin{array}{l}\text { S.2113v36-37: 迦葉佛亦從舍衛國騰空 } \\
\text { 而來于闐國人皆虔敬不可思議[其像亦把 } \\
\text { 袈裟] Kāśyapa Buddha also soared } \\
\text { through the air from Śrāvasti and } \\
\text { came to Khotan; the reverence [to } \\
\text { the statue] of the people was in- } \\
\text { conceivable [this statue also holds } \\
\text { a kāșāya] } \\
\text { P.3353r7-8: 迦葉佛亦從舍衛國騰空而來 } \\
\text { 在于闐國住國人虔敬無不遂願 [...the in- } \\
\text { habitants revered it and there was } \\
\text { not one whose wishes were not ful- } \\
\text { filled] } \\
\text { S.5659r10-11: 迦葉佛從舍衛國騰空而來 } \\
\text { 在于闐國住國人虔敬無不遂願 } \\
\text { D-MG 231: right: 迦葉佛從舍衛騰空 } \\
\text { left:於固城住 }\end{array}$ \\
\hline $\begin{array}{l}\text { 結迦宋佛 } \\
\text { Kāśyapa Buddha (?) }\end{array}$ & $\begin{array}{l}\text { 舍衛國 } \\
\text { Śrāvasti }\end{array}$ & $\begin{array}{l}\text { 固城 } \\
\text { “Old City" [of } \\
\text { Khotan] }\end{array}$ & $\begin{array}{l}\text { S.2113v21: 結迦宋佛亦舍衛國來在固城 } \\
\text { 住[其像手捻袈装] Kāśsyapa Buddha (?) } \\
\text { also came from Śrāvasti and set- } \\
\text { tled in the Old City [the hand of } \\
\text { this statue holds the kāșāya with } \\
\text { its fingertips] } \\
\text { D-MG } 76 \text { (caption partly damaged) } \\
\text { D-MG } 231 \text { (north) }\end{array}$ \\
\hline
\end{tabular}




\begin{tabular}{|c|c|c|c|}
\hline $\begin{array}{l}\text { AUSPICIOUS STAT- } \\
\text { UE/DEITIES } \\
\end{array}$ & MOVED FROM & \begin{tabular}{|l|} 
MOVED TO/ \\
RESIDES IN \\
\end{tabular} & SOURCES/REMARKS \\
\hline $\begin{array}{l}\text { Vipaśyin Buddha } \\
\text { 毗波户佛 }\end{array}$ & $\begin{array}{l}\text { 舍衛國 } \\
\text { Śrāvasti }\end{array}$ & $\begin{array}{l}\text { 于闐國 } \\
\text { Country of } \\
\text { Khotan }\end{array}$ & 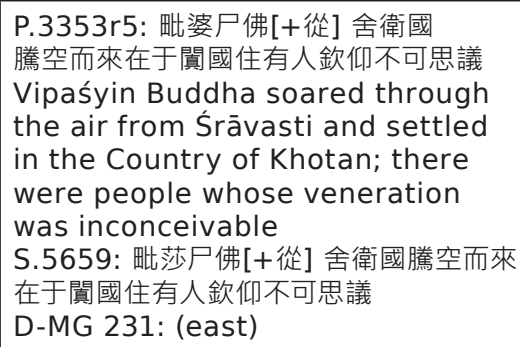 \\
\hline $\begin{array}{l}\text { 伽爾迦牟尼佛 } \\
\text { Jiâníjiāmóuní Buddha } \\
\text { (not identified Bud- } \\
\text { dha) }\end{array}$ & $\begin{array}{l}\text { 舍衛國 } \\
\text { Śrāvasti }\end{array}$ & $\begin{array}{l}\text { 固城 } \\
\text { “Old City” [of } \\
\text { Khotan] }\end{array}$ & $\begin{array}{l}\text { S.2113v38-39: 迦葉佛-伽儞迦牟尼佛從 } \\
\text { 舍衛國騰空而來在固城住 [其像手捻袈裟] } \\
\text { (note that there is a strikethrough } \\
\text { of the preceding 迦葉佛 Kāśyapa } \\
\text { Buddha) } \\
\text { D-MG } 76 \text { (caption damaged) }\end{array}$ \\
\hline \multicolumn{4}{|l|}{ Protector deities } \\
\hline & & & $\begin{array}{l}\text { The standard phrase for all the } \\
\text { protectors: "Deity X protects the } \\
\text { country of Khotan." The Sanskrit } \\
\text { transcriptions of the names of the } \\
\text { deities is based on Soymié } 1984, \\
\text { 86. Protector deities and bodhisat- } \\
\text { tvas are depicted in D-MG 9, 98, } \\
\text { 152, } 154\end{array}$ \\
\hline \begin{tabular}{|l|} 
迦迦那莎利神 \\
Deity Gaganasvara
\end{tabular} & & & $\begin{array}{l}\text { S.2113v48-49: 迦迦那莎利神守護于 } \\
\text { 闐國 }\end{array}$ \\
\hline $\begin{array}{l}\text { 莎那末利神 } \\
\text { Deity Suvarṇamāla }\end{array}$ & & & S.2113v49-50: 莎那末利神守護于闐國 \\
\hline \begin{tabular}{|l|} 
莎那摩利神 \\
Deity Suvarnamāla
\end{tabular} & & & S.2113v50: 莎那摩利神守護于闑國 \\
\hline $\begin{array}{l}\text { 阿隅闇天女 } \\
\text { Heavenly Maiden } \\
\text { Annkuśavatī }\end{array}$ & & & S.2113v50: 阿隅闇天女守護闐國 \\
\hline $\begin{array}{l}\text { 毗沙天王神 } \\
\text { Deity Vaiśravana }\end{array}$ & & & S.2113v51: 毗沙天王神守護于闐國 \\
\hline \begin{tabular}{|l} 
阿婆羅啠多神 \\
Deity Apārajita
\end{tabular} & & & 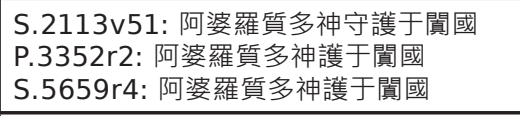 \\
\hline $\begin{array}{l}\text { 摩訶迦羅神 } \\
\text { Deity Mahākāla }\end{array}$ & & & S.2113v52: 摩訶迦羅神守護于闠國 \\
\hline $\begin{array}{l}\text { 悉他那天女 } \\
\text { 恭陀那天女 } \\
\text { Heavenly Maiden } \\
\text { Sthānavatī }\end{array}$ & & & $\begin{array}{l}\text { S.2113v52: 悉他那天女護于聞國 } \\
\text { S.5659r8: 恭陀那天女守護于閴國 }\end{array}$ \\
\hline \multicolumn{4}{|l|}{$\begin{array}{l}\text { Protector Bod- } \\
\text { hisattvas }\end{array}$} \\
\hline & & & $\begin{array}{l}\text { Same formula as in Protector dei- } \\
\text { ties. }\end{array}$ \\
\hline
\end{tabular}




\begin{tabular}{|c|c|c|c|}
\hline $\begin{array}{l}\text { AUSPICIOUS STAT- } \\
\text { UE/DEITIES }\end{array}$ & MOVED FROM & $\begin{array}{l}\text { MOVED TO/ } \\
\text { RESIDES IN }\end{array}$ & SOURCES/REMARKS \\
\hline $\begin{array}{l}\text { 金剛藏菩薩 } \\
\text { Vajragarbha Bod- } \\
\text { hisattva }\end{array}$ & & & S.5659r1：金剛藏菩薩護于闐國 \\
\hline $\begin{array}{l}\text { 觀世音菩薩 } \\
\text { Avalokiteśvara Bod- } \\
\text { hisattva }\end{array}$ & & & S.5659r14: 觀世音菩薩助于闐國 \\
\hline $\begin{array}{l}\text { 寶壇花菩薩 } \\
\text { Băotānhuā púsà }\end{array}$ & & & $\begin{array}{l}\text { S.5659r14-15: 寶壇花菩薩助于闐國 } \\
\text { (No reference to this Bodhisatt- } \\
\text { va other than in a caption of D-MG } \\
\text { 449) }\end{array}$ \\
\hline \multicolumn{4}{|l|}{$\begin{array}{l}\text { “NARRATIVES” MEN- } \\
\text { TIONING KHOTAN }\end{array}$} \\
\hline $\begin{array}{l}\text { 于闐王河浴佛瑞像 } \\
\text { The King of Khotan } \\
\text { bathing Buddha's } \\
\text { Auspicious Statue in } \\
\text { the river }\end{array}$ & & & $\begin{array}{l}\text { S.2113v22-23: 于闐王河浴佛瑞像身丈 } \\
\text { 餘杖錫持鉢畫形布(?)立[其像赤體立] The } \\
\text { King of Khotan bathes the Auspi- } \\
\text { cious Statue of the Buddha in the } \\
\text { river; the body [of the statue] is } \\
\text { more than [one] zhàng [in height; } \\
\text { i.e. more than } 3 \text { meters]; he holds } \\
\text { a monk's staff and begging bowl; ... } \\
\text { (?) [this statue is naked and stands } \\
\text { upright] }\end{array}$ \\
\hline $\begin{array}{l}\text { 于闐國舍利弗毗沙門天王 } \\
\text { Saarriputra and the } \\
\text { Heavenly King } \\
\text { Vaiśravaṇa of Khotan }\end{array}$ & & & $\begin{array}{l}\text { P.3352r11-12: 于闐國舍利弗毗沙門天 } \\
\text { 王決海時 } \\
\text { The scene when Śāriputra and } \\
\text { the Heavenly King Vaiśravana of } \\
\text { Khotan divide the ocean } \\
\text { D-MG 9, 237, 454 } \\
\text { D-MG 231: right:于闐國舍利弗毗沙門 } \\
\text { 天王決海時 }\end{array}$ \\
\hline
\end{tabular}

*On Phema, which is probably identical with Kănchéng 坎城, see the long internet article on that location by Lǐ 2015.

**Báitán xiāng 白檀香 means lit. "fragrance of white sandalwood" (Hirakawa, 863: Skr. caṇdanagandha), since the wood was used as incense; however, here, the term refers to the wood (compare Zieme 2006, 70 who translates an Uighur parallel passage of 白檀香 as “weisses Sandelholz"). The term also appears on P.2799 and P.3835.

\section{Comments to the table:}

The table lists only those among the Auspicious Statues/deities with explicit references to Khotan. The list of corresponding depictions in the Mògāo caves is incomplete. The caption texts of cave D-MG 231 are added according to Zhāng 2012.

Translations are added in the "Remarks" column only to narrative portions (i.e., sections which add information to the record of movement of a statue). The text in square brackets is originally written in small characters in the manuscripts, and describes iconographic features of the statues.

Among the manuscripts, S.2113 - P.3033 and P.3352 - S.5659, respectively, show particular similarities. P.3352 and D-MG 72 show several parallel passages (for a table, see Zhāng 2012, 416); also S.2113 and D-MG 76 show many parallels (ibid., 419). 


\section{The Interconnection of Khotan and Dūnhuáng}

In Dūnhuáng, the depiction of Khotanese protective deities is an iconographic element closely related to and often co-appearing with Auspicious Statues. ${ }^{32}$ Consequently, they will be discussed here briefly. Many key sūtras in China were also found as manuscript remains in Khotan, and references to the main protector Vaiśravaṇa can be found both in Khotan and Dūnhuáng. ${ }^{33}$ This combination of textual and visual sources is one of the indications that the ties between Khotan and Dūnhuáng were very close during extended periods. ${ }^{34}$ Especially after the Ān Lùshān 安祿山 rebellion (755-763) and its utterly devastating consequences for the Chinese government and general populace, the central Chinese government's control was considerably weakened, and, as a consequence, 'peripheral' regions (such as Dūnhuáng in the Northwest) gained power and quasi-independence. ${ }^{35}$ Indeed, the

32 Caves D-MG 9, 340, 39, 45, 98, 100, 108, 126, 146, 342, 397, 401, 25, 454; YL 33 (for a detailed table with the various deities and their placement in the caves, see Zhāng 2005, $56)$.

33 E.g., panel fragments and drawings of Vaiśravaṇa (Kha. i. 50, preserved in the National Museum of India, Delhi; see Williams 1973, 132-135); for a painting inscribed in Khotanese and Chinese, showing Vaiśravaṇa and Srī, see Williams 1973, 134. Shrine DII at Dandanuiliq (Dandan Oiliq) includes the depiction of Vaiśravana treading on a red demon, i.e., the 'Red-faces', as the Tibetans were referred to in the Prophecy of Khotan (Thomas 1935, vol.1, 78; Chandra 2006, 11, 14: “The D.Il shrine with the elegant mural of Hariti, of Vaisravana and of three other Lokapalas now lost, was a Temple of the Catur-maharaja based on the Suv. [Suvarṇaprabhāsa[uttamarāja] sūtra] for the protection of the kingdom of Khotan"). During recent excavations in Domoko (Dámăgōu 達瑪溝) between 2002 and 2010, a fragment of a mural in Temple 1 at Topulukdong was identified as Vaiśravaṇa depiction (however, this identification is doubted in Forte 2014).

34 See, for example, Mair 2012, 160 and Neelis 2012, 24. For a major recent study on KhotanDūnhuáng relations, see Róng and Zhū 2013 (since the present paper was already in publication when this work became accessible, the book could not be considered for the present study).

35 At the end of the eighth century, the government's control over the Tarim Basin was lost. 
weakness of the Chinese imperial bureaucracy was so great that Khotanese emissaries would at times refer to Dūnhuáng as 'China,' and send tribute there instead of to the capital (Hansen 2005, 37, analyzing Dūnhuáng remains on Khotanese tribute payments). After the Tibetans had occupied the area for more than 70 years, the so-called 'Return to Righteousness Army' (guīyì jūn 歸義軍) had regained Chinese control over Dūnhuáng in 848. This period, ${ }^{36}$ characterized by the rule of powerful local clans, lasted until approximately 1036, when the area was annexed by the armies of the Western Xià 西夏 Tanguts. Especially after the fall of the Táng Empire in 907, Dūnhuáng enjoyed nearly complete independence under the rule of the Cáo 曹 and Zhái 翟 families, and relations with Khotan as one of the key allies grew very close. ${ }^{37}$ These ties between Dūnhuáng and Khotan are also evidenced by the depiction of the King of Khotan on D-MG wall paintings. ${ }^{38}$ D-MG 98 is especially important in this context, and the painting of the king is situated in the main hall of the cave, wearing the cloth of a Chinese emperor. Indeed, the caption identifies him as the 'owner of the cave' ( kūzhǔ 窟主) and confers 'imperial' attributes on him:

大朝大寶于闐國大聖大明天子 即是窟主

36 For major studies of this historical period, see Zhèng 1997 and Zhèng 2003.

37 The large number of Khotanese people living in Dūnhuáng during the tenth century is also an indication for the close connections between the two areas of Khotan and Dūnhuáng (see Kumamoto 1996, Takata 2000, and van Schaik 2013, 14).

38 For a study of the iconographical motif of the King of Khotan, see Shā Wǔtián 2006. For a detailed list of Mògāo Auspicious Statues relating to Khotan and the interrelatedness of motives at the various locations in the caves, see Zhāng 2005, 56 (including D-MG 9, 340, $39,45,98,100,108,126,146,342,397,401,25,454)$. 
The great sage and greatly enlightened Son of Heaven, of the Great Dynasty and Great Treasure, the Country of Khotan, is the very owner of the cave.

D-MG 98 was the family cave of Cáo Yíjinn 曹議金 and was constructed between 923 and 925. During that time, the Cáo family tried to secure allies in the area: to the west through marriage relations with the family of the King of Khotan, Lĭ Shèngtiān 李聖天 (Viśa Saṃbhava, r. 912-966), and to the east with Uighur rulers of Gānzhōu 甘州. The other caves probably show the same Khotanese king and, in YL 31, he is accompanied by his wife and a child (or possibly servant). D-MG 4 also includes a depiction of the king and his wife, the features resembling D-MG 98; the positioning of the figures in the cave is similar here (Zhāng 2005, 23). D-MG 454 shows another person, probably Viśa Saṃbhava's successor Viśa Śūra (r. 966-977). ${ }^{39}$

As mentioned by Shā Wǔtián $(2006,23)$, in MG 220,40 the cave of a local dignity of Dūnhuáng, a special Manjuśrī painting was discovered, with features usually associated with Khotan. In the composition, Manjuśrī is not shown together with Samanthabadra (the co-appearance of the two figures is a common feature of Dūnhuáng iconography), but is instead accompanied by a figure which probably depicts the king of Khotan. The depiction also lacks other iconographical features usually associated with Samanthabadra. This 'new' iconography of Manjuśrī is also evidenced by depictions on manuscripts (e.g., Pelliot 4049). The same motif can be found in YL 19 (Five Dynasties) and YL 32. The theme of the Khotanese king also

39 In Khotanese, Dūnhuáng is referred to as Șācu; among the Tibetan texts on Khotan, a letter of Viśa Śūra to his uncle, the ruler of Dūnhuáng, is preserved (Bailey 1985: viii; see also van Schaik 2013, 14). Huò Dīliáng identifies the figure as the Uighur ruler of Gānzhōu (Tiānkèhàn 天可汗 'Heavenly Khan').

40 For a major study on this cave, see Ning 2004. 
appears in a scene of the famous and monumental 'Mt. Oxhead map' in MG 454; the captions related to Khotan read:

\section{于闐王誠心禮請釋迦}

The King of Khotan pays obeisance to Śākya [i.e., the Buddha] with an honest heart

\section{毗盧遮那阿羅漢請于闐王修建德佛寺}

Mahāvairocana [Buddha] and [?] arhats request the king of Khotan to repair the Virtue Buddha Temple

\section{于闐國都城}

The capital of the Country of Khotan

Whereas depictions of protective deities and other narratives on Khotan are frequently encountered from mid-Táng times onwards in the Mògāo caves, there is also evidence of these topics in Khotan itself, both in terms of literary production and iconographic representation. Among the findings, Shrine D II was connected to Vaiśravaṇa and the female deity Hāritī. ${ }^{41}$ The

41 Ch. Guǐzĭ mǔshén 鬼子母神 (lit. 'Mother Spirit of the Demon Children;' T.16, no.663: 335b28; Skr. hārītī bhūta-mātā); she is said to protect children and help women during their pregnancy. Originally, the deity was actually not benevolent but killed the children of others in order to feed them to her own hungry offspring (which, by the way, numbered several hundreds) until she was converted by the Buddha and transformed into a guardian deity. 
Suvarnaprabhāśa sūtra ${ }^{42}$ on the protection of the state by four guardian deities (hù siwáng 護四王) was probably one of the major inspirations for the development of these ideas, linking Buddhism with state government. As David Chappell notes, the text played an important role in state rituals of China and Japan, "[...] but the most striking feature of this form of Buddhist confession was the theistic function of the buddhas, who were asked to give protection and to forgive all evil deeds." (Chappell 2004, 812) The compilation of the text in northern India or Central Asia is assumed to have occurred between the first and third centuries CE:

Most of the sūtra's seemingly disparate parts share an emphasis upon the transformative power of the sūtra itself, represented as golden light that infuses its preachers and auditors. The role of the sūtra in protecting and sustaining the kingdom of the ruler who accords it appropriate respect is another dominant theme. (Ibid.)

Sanskrit fragments of the text were found in Khotan and were translated into Khotanese during the fifth/sixth century. From the mid-Táng period onwards, there are 11 Sūtra Transformation Tableaux of this text (Wu 1992, 129).

42 Skr. Suvarṇaprabhāsottama sūtra/Suvarṇaprabhāsa[uttamarāja] sūtra, Ch. Jīn guāngmíng jīng 金光明經 ('Golden Light sūtra') or Jīn guāngmíng zuìshèng wáng jīng 金光明最勝王 經, ed. in T.16, nos. 663, 664, 665. On this text, see Chappell 2004, vol.2, 722. For the very substantial remains of the Khotanese version of this text, see Skjærvø 2004. For a translation, see Emmerick 1992. For a recent major study of Khotanese-Chinese parallel texts (including translations into Modern Chinese), see Duàn Qīng 2013 (on the above text, see 185-201). 


\section{The Rescue of Khotan by Śāriputra and Vaiśravaṇa}

The rescue of Khotan by Śāriputra and Vaiśravaṇa is one of the founding legends of Khotan, and the popular story was depicted in Dūnhuáng from the mid-Táng period onwards. It was often integrated in the Auspicious Statues assemblies and was also a mandatory element of Oxhead Mountain depictions. The narrative deals with the collaboration of Saariputra, one of the foremost disciples of Buddha, and the protective deity Vaiśravaṇa, joining efforts in order to drain the lake covering the area of Khotan (for a synopsis of the story, see footnote 44). The emergence of the story on the walls of Dūnhuáng is significant because it does not appear in any canonical source, but seems to have developed as a local narrative of Khotan and eventually spread to Dūnhuáng based on the close connections between the two locations. ${ }^{43}$ Illustrations can be found in several caves, ${ }^{44}$ often together with images of other protective deities (hùguó tiānwáng 護國天王). The topic of divine drainage also appears in a narrative of the Prophecy of Khotan: Only after the arrival of Śākyamuni in Khotan, the lake is drained

43 Interestingly, Făxiăn does not mention the founding legend of Khotan in his travel diary; possibly, the founding myths were not yet systemized at that time (see Deeg 2005, 88). Early elements of the legend about Buddha visiting Khotan can be traced to the beginning of the fifth century (the event was 'sanctioned' as historical fact through the production of the apocryphal Sūryagarbhavaipulya sūtra, Rìzàng fēn 日藏分 (part of T.14, no.397; see ibid.)). Concerning the veneration of statues, Fǎxiăn gives an account of a festival with processions of the statues by each of the 14 monasteries on consecutive days (Deeg 2005, 92-93): “Dies könnte durchaus bedeuten, daß die Statuen sich auf die in den (späteren) Legenden vorkommenden Gestalten bezogen haben: der Buddha selbst, der Khotan besucht hat, Vaiśravaṇa, aus dessen Kopf der “Urkönig" Khotans, Sanu-Gostana, geboren wurde, Vairocana, der den Buddhismus ins Land gebracht hat, und andere."

For a very good contextualization of the founding legends in the Central Asian context, see Davidson 2002.

44 E.g., D-MG 237 (mid-Táng), D-MG 9 (Late Táng), YL 32 (Five Dynasties), D-MG 454 (Sòng). 


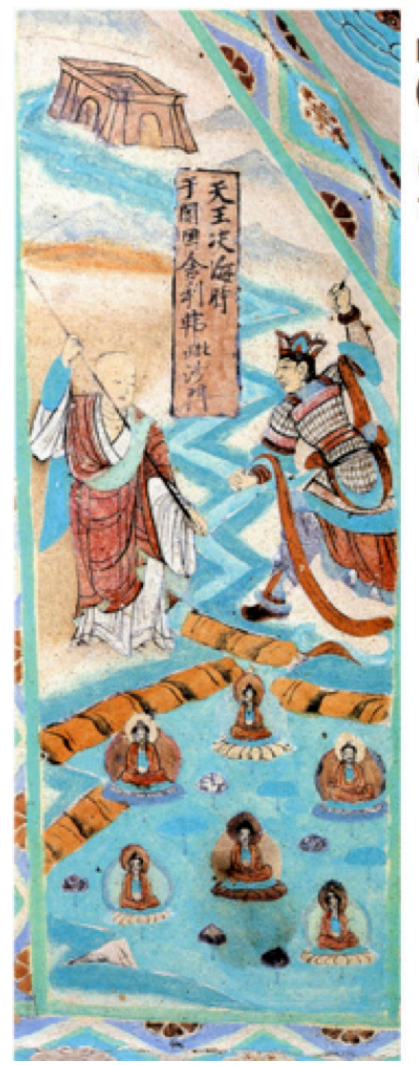

MG 237
(mid-Táng)
Caption
Text:
天
王
決
海
時
于
闐
國
舍
利
弗
毘
沙
門
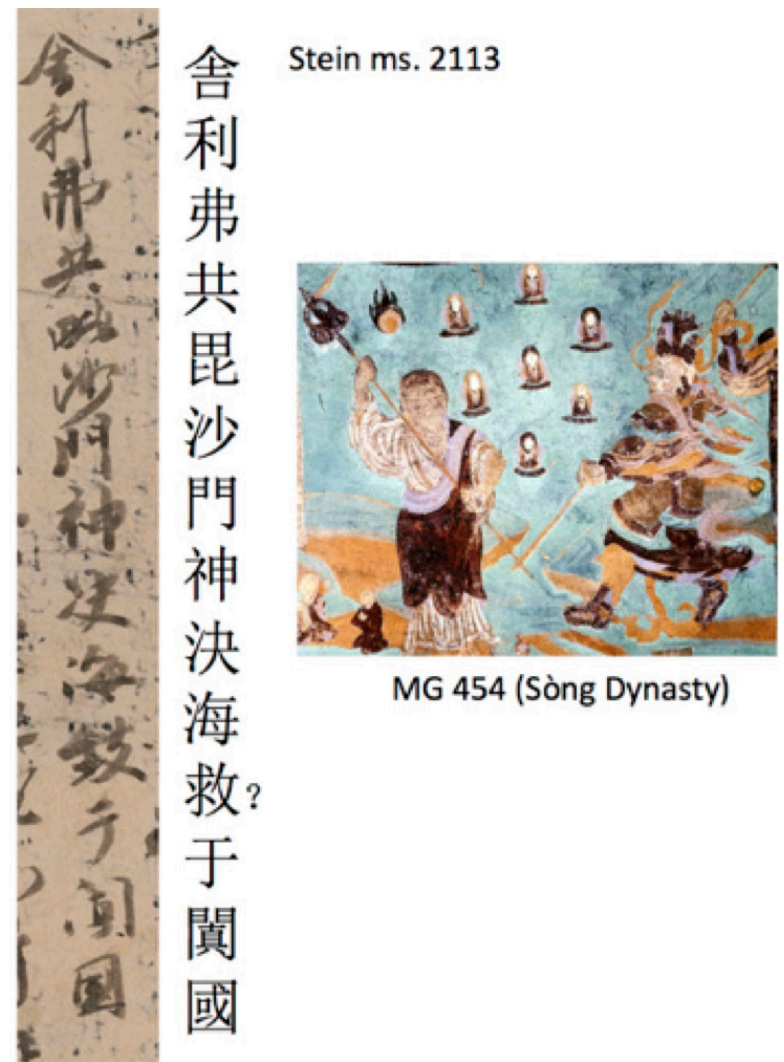

MG 454 (Sòng Dynasty)

FIGURE 7 (left) reproduced from Sūn Xiūshēn 2000, 72, ill. 56.

FIGURE 8 (middle) passage from Stein 2113.

FIGURE 9 (right) reproduced from Sūn Xiūshēn 2000, 73, ill. 57.

The depiction of the topic is rather standardized, as the comparison between the illustrations in D-MG 237 from the mid-Táng (left), and D-MG 454 from the Sòng period (right) show. D-MG 237 also includes a caption text: 'The scene of heavenly kings draining the ocean.' Ms. Stein 2113 (middle) has the following entry: 'Sāriputra and the deity Vaiśravaña draining the ocean and saving Khotan.' 


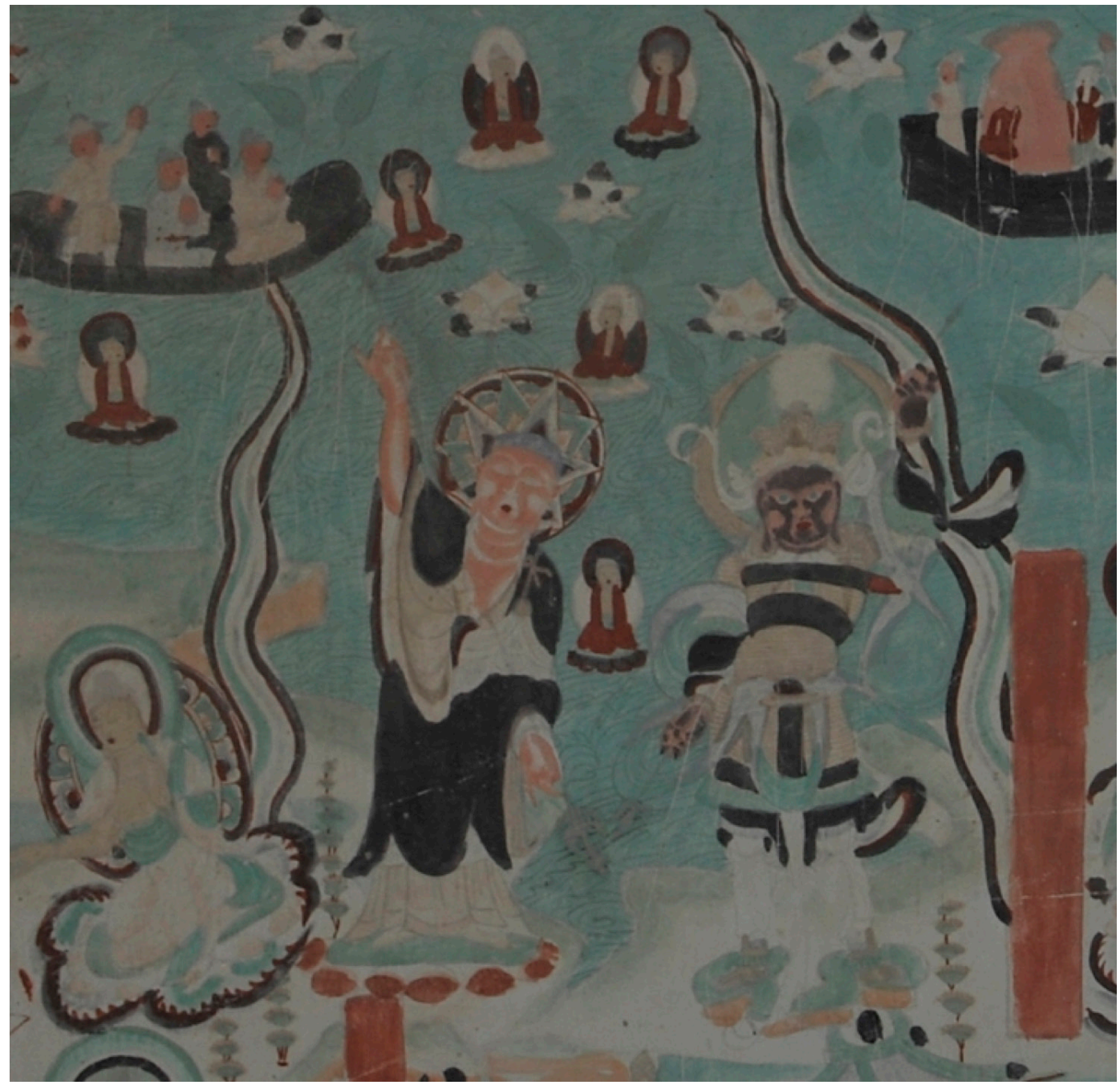

FIGURE 10 Detail of the Oxhead Mountain tableau in Cave YL 33, reproduced with the permission of the Dūnhuáng Academy. 
and protectors of the region are appointed. ${ }^{45}$ The topic of the rescue of Khotan is integrated in a monumental Oxhead Mountain depiction, including several narratives related to Khotan and the transmission of Buddhism (Fig. 7). ${ }^{46}$

According to some interpretations, the story takes place in the time of Kāśyapa Buddha (Jiāshè Fó 迦葉佛). However, it is more likely that the narrative involves Śăkyamuni and that the main motif is the conversion of the people of Khotan to Buddhism. In this story, one of the protagonists is an originally resentful nāga deity who demands offerings from the people every year. After Buddhism was adopted, the offerings were neglected, inciting the dragon's fury, which consequently transformed the location into a huge lake. When Buddha witnessed the suffering of the people he sent his disciple Śāriputra to the location. Joining forces with Vaiśravaṇa, they opened the shores of the lake and released the water, transforming the area into a habitable place once again. As a consequence, Buddhism

45 For a list of these protectors, see Emmerick 1967, 3, 9, 13, and Chandra 2006, 3. The main protector is Vaiśravana (Thomas 1935, 19, 21, 28; for more references, see Chandra $2006,7-8)$, who also controls the army of yakșas. The same text also states that Khotan was a country "where Indians and Chinese met" (Emmerick 1967, 21, 23). On the legend of draining lakes through deities in an interregional context, see Brough 1948 (observing a particularly close similarity between accounts of Khotan and Nepal). The Gośrngavyākaraṇa gives an account of Śākyamuni arriving at Gośrńna in Khotan. Seeing a great lake, he promises a great future for the location and orders Śāriputra and Vaiśravaṇa to use their monk's staffs to drain the area: “[...] dried half of the mountain of Śa, and, taking it, set it down on the western side and made a great water course. The lake with its living beings they transferred into the middle of Śo-rtsan-po [a mountain (?) on the north of the lake]. In this way they disclosed the stūpa of Go-ma-sa-la-gan-da and the hill of Gośrnga and the land of Li." (Brough 1948, 333, based on Thomas 1935, vol.1, 12-35).

46 Note that a minor iconographic 'mistake' can be observed in the depiction: the artist added a halo to the figure of Śăriputra on the left side (halos are usually reserved for buddhas and deities). He might have done so because the lower part of the tableau shows dozens of Auspicious Statues, all with halos. Since the figure of Śāiputra resembles some of the Auspicious Statues, he might have unconsciously added the halo. 
started to flourish in the area. Similar stories were also recorded from other places, with different protagonists (i.e., in Nepal and Kashmir).

The story appeared during the mid-Táng (D-MG 231 and D-MG 237), and until the early Sòng it remained a popular theme in Dūnhuáng. It is often depicted in the entrance tunnels to the caves (e.g., D-MG 474). The narrative does not appear in 'canonical' sources but is recorded in Tibetan historiographies. ${ }^{47}$

\section{The Emergence of Vaiśravaṇa as a Protecting Deity of Khotan}

Before the appearance of the textual and visual narratives in Khotan and Dūnhuáng, it seems that Vaiśravaṇa was a deity of rather secondary importance in Asia, having only a supportive role rather than being featured as a main protagonist (see Pons 2014). ${ }^{48}$ The Dīrghāgama has the following characterization of Vaiśravaṇa:

北方天王名毗沙門。領諸悅叉鬼。有大威德。有九十一子。亦字因陀羅。有大神力・此四天 王護持世者。有大威德。身放光明。

47 For the Tibetan version, see ms. Pelliot Tibétain 960; see also Zhāng 2008, 9.

48 Vaiśravaña also appears in non-canonical material discovered among the Dūnhuáng manuscripts, e.g., Fó shuō běifāng dàshèng Píshāmén tiānwáng jīng 佛說北方大乘毗沙門天 王經, Píshāmén yuánqǐ 毗沙門緣起, Píshāmén shénmŭ jīng 毗沙門神母經 (see Chén Huáiyǔ 1987: 149, fn.41). On studies of earlier iconographies of Vaiśravaṇa (Bharhut, Sāñcī, Dandan Uiliq), see Filigenzi \& Maggi $(2008,84)$, who also point out the features which transformed the iconography in a local context. For a major study on Vaiśravana, tracing the developments in India, China, and Japan, see Granoff 1970. 
The Heavenly King of the Northern Region is called Píshāmén (Vaiśravaṇa). He is leading the yakșa demons and has great powers. He has 91 sons and is also referred to as Yīntuóluó (Indra), having great supernatural powers. These four Heavenly Kings protect the world and are in possession of great powers. Their bodies emit light. (T.1, no.1: 80a6-8)

The protection of locations and, more generally, of the state by powerful deities developed into a very important feature of East Asian Buddhism, and the gods of the four directions played a major role in this respect. ${ }^{49}$ According to sources in old Uighur of the tenth century, Vaiśravaṇa (> Vaišravani) was also a protector of the Buddhist clergy. ${ }^{50}$ The encyclopedic Făyuàn zhūlín 法苑珠林 (668) provides early reference to Vaiśravaṇa in the Chinese context (see fascicle 39), giving a report of the construction of a temple in (today's) Nánjīng 南京 in 474, with a relic and the painted figures of Kapila Devarāja and Vaiśravaṇa:

This is our first reference to the Guardian King of the North. It is conceivable that he was painted with his companion on the rear surface of the wall behind the main image, so to face the rear door, and stand guard against the especially malign influences that might threaten from the North; i.e. in the position of the threatening Vajra-bearer at the rear of the eight century Hokkedō of Tōdaiji, at Nara in Japan. (Soper 1959, 56)

49 Skr. catur mahārāja; usually referred to as the 'Four Heavenly Kings' (sì tiānwáng 四天王) or the 'Four Great Heavenly Kings' (sì dà tiānwáng 四大天王) in Chinese; the fours lokapālas and their respective directions are as follows: Dhṛtarāṣțra (east), Virūọhaka (south), Virūpākșa (west), and Vaiśravaṇa (north).

50 See Zieme 2006, 8, 31, who argues that the Āțānāțikasūtra/ Āțānāțikahrdaya is basically the same concise text as the later (Fó shūo) Píshāmén tiānwáng jīng (佛說) 毘沙門天王經, Sūtra on the Heavenly King Vaiśravaña spoken by the Buddha, (*Vaiśravaṇa-devarājasūtra, T.21, no.1245; translated in the late tenth century). 
The protector also appears on a stele at Shàolín 少林 Monastery in Hénán Province, erected in 535. The main niche is occupied by Śăkyamuni, accompanied by Avalokiteśvara and Mañjuśrī bodhisattvas, while the figures of Brahmā and Vaiśravaṇa appear in the arch frame. The Seven Buddhas are spread in small niches across the top (128); this is of significance because in Dūnhuáng depictions, the draining of the Khotanese lake by Saariputra and Vaiśravana includes the iconographic feature of seven small Buddha statues floating in the water. As such, cross-regional iconographic features stretching from Khotan to Dūnhuáng and central China seem to have been established at an early time already, and the Vaiśravaṇa cult was spreading swiftly to these regions. The importance of Vaiśravana in China can be also deduced from an edict issued by Emperor Wŭ of the Liáng Dynasty in 513, exempting animal sacrifices to the lokapālas from a general ban of these practices (229). The iconographical representations of Vaiśravaṇa also spread from the center to the Sìchuān region ${ }^{51}$ in southwestern China from the mid-Táng period onwards (with many sculptures in the area of Chéngdū, as protector against calamities, usually together with the 1000-armed Avalokiteśvara).

Among the manuscript findings from Dūnhuáng, there are several items containing elaborate paintings and drawings of the deity. Simultaneously to the development of Vaiśravaña into a main deity of the area of Khotan, significant changes of the iconographical representation are observable.

The iconography of Vaiśravaṇa shows resemblances with depictions preserved among the Dūnhuáng Tibetan manuscripts (Pelliot Tibetain $2222,2223,2224)$. In some of these paintings, as well as on the Stein Silk

51 On Sìchuān as an early center of the Vaiśravaṇa cult, see Granoff 1970, 155. The author also emphasizes the role of esoteric masters, such as Amogavajra, in the spread of the cult in China (149). Another indication of the quick spread is the early introduction to Japan in the ninth century (144). 
painting 133, the Earth Goddess (Prthivī) is supporting the feet of the deity. This is a feature unattested in previous iconography on Vaiśravaṇa. ${ }^{52}$

On Pelliot 4518(27), there are two additional figures, one to the right, one to the left, and a kneeling donor on the lower right side. Vaiśravaṇa is holding a lance in his right hand and a stūpa with his left. ${ }^{53}$ To his left is probably a Dharma-protecting Gandharva (Qiándápó 乾達婆), wearing the skin of a tiger, with the left hand holding a 'golden mouse' (jīn shŭ 金鼠) and the fingers of the right hand pinching a silken thread. ${ }^{55}$ To his right is Lakșmī̄5/Srīdevī (Gōngdé tiān 功德天), wearing non-Chinese clothes,

52 Prthivi appearing from the ground is usually associated with the iconography of the temptation of the meditating Buddha by the Demon King Māra. As pointed out by Filigenzi and Maggi $(2008,83)$, this motif alludes to the founding myth of the dynasty of Khotanese kings: "The presence of the earth goddess is reminiscent of the legendary origin of the royal lineage, according to which Vaiśravana would have granted a son to the childless king of Khotan. This child refused normal milk and so was suckled by a breast emerging from the earth."

For a thorough comparative study of the iconography, see Granoff 1970.

53 The structure does not show the usual features of a stūpa. Possibly, it depicts a 'familystūpa,' which, according to Făxiăn, was a popular object of devotion in many individual households of Khotan (on this practice, see Deeg 2005, 69). However, this interpretation is purely speculative.

54 On narratives concerning the 'golden rat,' see the entry on '金鼠' in Dìng Fúbăo 1984.

55 It is actually not quite clear what this refers to; possibly, it is an allusion to the following narrative, which also features a mouse and a thread. Făxiăn records a narrative according to which heretics start a denunciation campaign against the Buddha. They convince the female ascetic Ciñcāmānavikā to visit the Buddha in Jetavana and not to return before the next morning, pretending to have spent the night with him. Consequently, she fakes a pregnancy by binding an object on her belly. Śakra is enraged and transforms into a mouse, gnawing through the thread holding the object in front of her belly in place. For her attempt of deceit, she is submerged into hell (Deeg 2005, 310-311). However, it is not quite clear to me why this story should be alluded to in the Vaiśravana iconography. It is more likely that the rat might be a reference to stories in which these animals contributed to the defeat of enemy armies by eating their arms (on details of this narrative and the connection with the Vaiśravana cult, see Granoff 1970, 150).

56 Shā Wǔtián (2006) identifies the female figure as Lakșmī, who symbolizes the attainment of wealth. From early on, Lakșmī became an important deity in Japan as well (based on 
possibly a Khotanese dress. Opposite the donor is the depiction of a Vināyaka (Pínàyèjiā 毗那夜加) with the head of an elephant. ${ }^{57}$

The painting has bilingual inscriptions, two in Chinese and one in Khotanese. The Chinese inscriptions are as follows:

王上卿天王 /一心供養

Offered singly-mindedly by the devarāja Hvāṃ’ Śāṃ Khīnä (> Wáng Shàngqiing)

一心供養張 / 儒(者 ?) $)^{58}$

Single-mindedly offered by Zhāng Rǔ (?) ... 59

There are also three lines of Khotanese text; the painting probably dates from the tenth century (the 'Year of the Hare' would correspond to 943): ${ }^{60}$

Hvāṃ':śām-khīnä pasti pĩ ḍe, bu'ysye jsīña

Priyavgä vdiśāyä. sahaicä salya

Didye māśta iomye haḍai navda

Hvāṃ': Śāṃ-Khīnä ordered (this painting of Vaiśravaṇa) to be

the Lakșmī chapter of the Konkōmyō saishōōkyō 金光明最勝王經).

57 Vināyaka is an alternative name for the elephant god Ganeśa.

58 For an edition of the inscriptions, see Dudbridge \& Emmerick 1978, 283-285. The second Chinese caption is right above the depiction of the donor. The Khotanese transcription and translation is according to Filigenzi and Maggi $(2008,85)$.

59 The last character is difficult to read, possibly being a 者.

60 Zhāng and Róng (1986) provide a Chinese translation of the Khotanese caption: 王上卿令 绘( 此图)，惟愿长生福庆，(卯) 兔年三月十日敬讫. 
painted for the sake of the enjoyment of a long life in the year of the hare, in the third month, on the tenth day. Homage.

Stein painting 245 shows the image of Vaiśravana printed for Cáo Yuánzhōng; the Earth Goddess is also depicted in this composition, supporting the deity's feet. In addition to Lakșmī, there is a Yakșa to his upper left, holding a small boy. On the lower part of the print there is the dedication text by Cáo Yuánzhōng.

\section{Reflections on the Appearance of the Auspicious Statues}

From the mid-Táng period onwards, the focus of Buddhist art in the Mògāo caves of Dūnhuáng had shifted to the large-format Transformation Tableaux, illustrating key Mahāyāna texts. ${ }^{61}$ Simultaneously, there is evidence of increasing interest in relating to the 'origins' of Buddhism, its transfer to China, and its localization in the 'Eastern regions.' On the one hand, the historiographical projections reflect a deep fascination with pilgrim travels and their descriptions of important Buddhist locations in their travel diaries (Dūnhuáng was an important city for pilgrims on their route to India and for Indian and Central Asian monks and translators on their way to the Chinese capitals), as well as key events described in Chinese Buddhist historiographies. In these types of narratives, the transmission is clearly

61 It should be mentioned here that the Transformation Tableaux were depicted throughout China in caves and monasteries during the Táng period (probably spreading from the Chinese central areas to Dūnhuáng). However, very few original monastic structures have survived and, thus, the existence of the tableaux must be mainly deducted from literary sources. A very useful study of literary sources concerning murals in Táng and Five Dynasties monasteries is Mă 2012. 
based on human agents and concrete movements between locations related to the biography of the founder of the religion. The narratives also reflect a period of 'consolidation' and looking back, trying to connect the firmly established Chinese varieties of Buddhism with their 'origins' in India. These are certainly indications of 'sinization' processes, and 'Chinese' Buddhism (and forms of localized Buddhism(s) in the Tarim Basin and the northwestern regions) are connected and at the same time demarcated from the 'origin.' In this paper, the focus was on the issue of both real and projected transmission processes (especially via Khotan), on imaginations related to the coming of Buddhism to the Tarim Basin and China, as well as on motives of conversion and protection in the form of narratives rationalizing the long-term establishment of Buddhism in these regions. Surveying the extant material in Dūnhuáng, many questions remain. The development of the Vaiśravaṇa cult in China and Dūnhuáng can be traced rather convincingly and is also clearly reflected in remains from Khotan. Certain questions remain, however: when exactly did the Vaiśravaṇa cult in Khotan arise; was it in fact earlier than in China? Did it spread from there to China? The exact timeline of developments is also problematic with regard to the founding legends of Khotan. Indeed, when exactly did these legends arise? The greatest puzzle, however, are the Auspicious Statues. They are an important iconographic genre in the Mògāo caves and are also reflected in the Dūnhuáng manuscript remains. Alternative sources, however, are scarce (except for the 'master narrative,' the Udayana Statue) and do not seem to be reflected in material from Khotan at all. Most of the Dūnhuáng representations of the statues date from a period when Dūnhuáng-Khotan relations were very close. Are they mere projections of the significance of Khotan concerning the transmission of Buddhism? Or do the narratives rooted in Khotanese legends point to the arrival of Auspicious Statues? Indeed, we do not really require any additional material in order to explain 
the appearance of most of the approximately three dozen statues. With a few exceptions, the narratives can be traced to the reports on famous statues recorded in the travel logs of Chinese monks.

There are complex dynamics developing based on a variety of factors, and in the case study of Vaiśravana, the socio-political context plays a significant role. The promotion of Vaiśravana to the main protective deity of Khotan not only triggered a set of new narratives but also significant changes in the iconography (as well as the elements and agents included in the depictions). The paintings at Dūnhuáng, Mògāo in the tenth century made the political and exogamous relations even more explicit. This might be one of the reasons why the depictions often do not programmatically relate to other elements in the caves. ${ }^{62}$

\section{Contextualization and Final Reflections}

Beginning from the seventh century, historical projections found in the Dūnhuáng area in the form of iconographic representations and popular narratives are paralleled on a more scholastic and sectarian level by the production of transmission histories, especially in the context of the early Tiāntái 天台 and Chán 禪 movements. It was common in these approaches to attempt to connect to the 'source' (both imagined and as a concrete location during pilgrim travels) and, at the same time, establish an individual

62 The relationships between the paintings on the walls of the Buddha niches and their respective icons are difficult to determine, since very frequently the icons of the niches are not extant (Sūn Xiūshēn 1986, 17). But it is unlikely that corresponding Auspicious Statues were placed in these Buddha niches. As was pointed out by Schmid (2006), there is of course a difference between images which directly refer to divinities and "painted Auspicious Images" in Dūnhuáng, which refer to the statues of the divinities. They are often situated between the beams dividing the ceiling of the niches into sections. 
"Chinese" Buddhist identity, thereby firmly localizing Buddhism in its new environments. The exact circumstances of these complex developmentsand whether there is a connection between them-requires more thorough studies, and the emergence of alternative transmission narratives (as exemplified by the legends concerning the foundation of Khotan and, much later, the flying buddhas/bodhisattvas as depicted in Dūnhuáng) are possibly related to historical events at locations along the Silk Road and subsequent larger transformations in these areas. ${ }^{63}$

Recently, Claudia Wenzel (2011) published an interesting study on 'iconic' and 'aniconic' traditions in India and China, and discussed various types of image cult and differing attitudes towards image production in China. She emphasizes the significance of the origin of images (exemplified by the widespread Aśoka image cult; 279). This raises the more general question of where the 'true countenance' (zhēnróng 真容; 281) of the Buddha can be found, either in iconic (and, more specifically, in which one) or aniconic forms (e.g., beyond images and texts).

It is safe to say that this tension between extreme image veneration, on the one hand, and the focus on the "formless" features of true Buddhahood beyond any spatial and temporal restrictions (Buddha in the aspect of dharmadhātu), on the other, were important driving forces in the development of Chinese Buddhism. Auspicious Statues were thought to incorporate the qualities and powers of their origin. They were the ideal medium to represent aspects of origin, transmission, and relocation. As in the context of sectarian transmission histories of Tiāntái and Chán (although achieved through different means, media, and genres), there is

63 An early example is the fall of the Kushan Empire and the subsequent weakening of the relations with India. As Johan Elverskog has pointed out (personal communication), actual relics were perhaps no longer so easily accessible, and new methods of relating to the sacred were needed. 
an emphasis on the following feature: there is no decline of quality in the transmission of the Buddha-Dharma based on the distance in time and space. On the contrary, the "true Dharma" (or, as Chán Buddhists would say, the "Buddha Mind," fóxīn 佛心) had arrived at a new location (e.g. Khotan or China). This concept is indeed very different from theories concerning the gradual decline of Buddhism or the final period of the Dharma (mòfă 末 法), very popular in China from the fifth/sixth century onwards. According to these theories, temporal and spatial distance from Śākyamuni Buddha necessarily will entail a decline and thinning out of his teachings, and this temporal process is frequently specified numerically in several scriptures. Only the appearance of a new Buddha (i.e., Maitreya) can "refresh" the power of the Dharma.

Since Auspicious Statues were thought to have been ultimately created "face to face" with the Buddha or their "original," they consequently incorporated his powers (one could even go as far as stating that they were his "doubles"). The emergence of these narratives are highly interesting, since, on the one hand, they seem to fulfill similar functions as relics, i.e., they can be moved and distributed, are related to locations, and are the object of worship. On the other hand, Auspicious Statues are not remains, but representations of Śākyamuni (and other bodhisattvas and sages) when alive. They are self-aware and in possession of independent willpower. Auspicious Statues have the ability to determine their movements and can directly react to the needs of worshippers in specific situations. On a more metaphorical level, one could say that they represent a living and actualized Dharma. Whereas the spatial dimension of transfer is very concrete (i.e., the movement from $X$ to $Y$ ), the temporal dimension is nearly reduced to simultaneity between the beginning and the end of this movement. In contrast to the lengthy and strenuous travels of the pilgrims visiting the various Buddhist places, the statues are airborne and are transferred 
speedily from their origin in India (or wherever they come from) to their point of destination. Indeed, instantaneous movement through the air also bridges the gap between "center" and "periphery" (i.e., the original of the center becomes the original of the periphery) and, as such, transcends gaps in space and time.

Originally emerging from one master narrative (the Udayana image), a variety of stories concerning Auspicious Statues emerged in the form of "mirror narratives," which structurally show great similarities but employ different sets of protagonists. Common to all of these narratives are the distinct features of mobility and the ability to move through the air extremely fast ("move and reside," as frequently seen in the captions and the descriptions in the manuscripts). Whereas many of the mirror narratives, as depicted in the Mògāo caves and described in a number of manuscript texts, mention well-known buddhas and bodhisattvas, there are also Auspicious Statues which have not yet been identified and probably reflect local legends and narratives not extant any more.

Transmission theories and soteriological schemes developing from roughly the early Táng period onwards (and drawing from earlier discourses, for example on the Buddha-nature and the purity of mind theories) elegantly bypass the gaps in space and time and the remoteness to the time of Śākyamuni. In the case of Auspicious Statues, this is achieved through the creation of images of being "face-to-face" with Buddha (or other sages), and, consequently, of acting on behalf of their origin. As compared to developments on a more scholastic level, a similar emphasis on immediacy and relocation of the Buddha's "essence" into new environments is observable; in Chán Buddhist historiographies, for example, this works through the assumption of a transmission which takes place "from mindto-mind." The early Chán transmission histories date from around the late seventh and the beginning of the eighth century and construct a lineage 
connecting the Chinese "patriarchs" and famous masters with a sequence of Indian patriarchs and the Buddha himself (in addition to several buddhas of the past). These early records were not transmitted after the emergence of more standardized accounts during the end of the Táng and early Sòng periods, but are fortunately preserved among the Dūnhuáng manuscripts. In contrast to the transfer and transmission discussed in the framework of Auspicious Statues here, Chán transmission had a great focus on an uninterrupted sequence of individuals, inheriting and passing on the very Buddha-mind. As such, the very essence of Saakyamuni is thought to be transferred from India to China, implying that the essence of the Buddha finally arrived in China. There are certainly similarities to the concept of the "actualized" Buddha or Bodhisattva as manifested in the form of Auspicious Statues. In future studies, this aspect of "instantaneous" transmission and the de-emphasis of the temporal dimension in Chinese Buddhism ${ }^{64}$ (and, as a consequence, the weakening of the basic Buddhist tenet of cause and effect, which is heavily time-dependent), as well as the numerous soteriological "short-cut" approaches developing during the Táng Dynasty, must be contextualized in much greater detail. ${ }^{65}$

Another focus of this paper, and closely connected to the popularity of the theme of Auspicious Statues, was the area of Khotan and its relationship to Dūnhuáng. The area of Khotan seems to have played a decisive role in the spread of Auspicious Statues narratives to Tibet and China; although, at this point, this cannot be verified through archeological remains. In

64 Concerning the disappearance of the temporal dimensions in medieval Chinese and, by consequence, the workings of cause and effect, I am indebted to discussions with Jörg Plassen (Ruhr-Universität Bochum) on this subject.

65 Including the countless short apocryphal sūtras which instruct the reader on their own soteriological efficacy (generated by the mere act of reading and copying); the selfreferential features in these texts are drawn to a fascinating extreme, to my knowledge previously unattested in Buddhist literature. 
Dūnhuáng, both the close political ties as well as the significance of Khotan for the transmission of Buddhism to China are clearly reflected. Through this translocal network, new narratives and iconographic representations were generated, such as the numerous paintings of Khotanese protective deities, stories on conversion in the area of Khotan, and accounts of the movement of Auspicious statues to that location. Khotan also seems to have been a key location in the dissemination of important scriptures, concepts, and cults. The sources also allow us direct insight into the dynamics of politics and religion, including the emergence and spread of new sets of narratives and forms of iconographical representation. The popularity of the depiction of Auspicious Statues in Dūnhuáng can be related to the close political ties with Khotan. This is also supported by the fact that Auspicious Statues lost their significance in the art of Dūnhuáng after the decline of the close relations to Khotan.

\section{Acknowledgements}

This paper is part of a larger project on historical and 'Auspicious Statues' narratives and iconography emerging from roughly the mid-Táng onwards in the area of Dūnhuáng. I want to express my special thanks to the two anonymous reviewers who provided numerous essential comments and corrections on a draft version of the paper. I am also indebted to the following scholars for their valuable comments on the paper: Isabelle Charleux for providing initial bibliographical material on the Udayana Auspicious Statue narrative; Neil Schmid and Johan Elverskog, for thoroughly reading through the paper and providing a wealth of valuable suggestions; to Mauro Maggi and Erika Forte for providing information on the Khotanese inscriptions, iconography, and secondary literature on Khotan; and Jessie Pons for her 
comments on the Vaiśravana iconography. Research on the article was conducted within the framework of the "Dynamics of Text Corpora and Image Programs: Representations of Buddhist Narratives Along the Silk Road" project, funded by the Mercator Foundation, and a Visiting Research Fellow grant provided by the Käte Hamburger Kolleg, Ruhr-Universität Bochum. I also want to express my gratitude to Prof. Luó Huáqìng 罗华庆 from the Dūnhuáng Academy for granting the permission to reproduce the photographs of Auspicious Images (Mògāo caves).

\section{Reference List}

Bailey, H.W. 1985. Indo-Scythian Studies: Khotanese Texts. Volume 7. Cambridge: Cambridge University Press.

Bělka, Luboš. 2006. "Zandan Zhuu and the Buryat Sangha: History and Present State." In The Ecological Problems and Spiritual Traditions of the Peoples of the Baikal Region, edited by UlanUde, 143-152. Izd-vo GUZ.

- - - 2010. "Spread of Buddhism and Wandering Statues: Case of the Beijing Sandalwood Buddha." Studia Asiatica: International Journal of Asian Studies 11/1-.2: 197-214.

Brough, John. 1948. "Legends of Khotan and Nepal." Bulletin of the School of Oriental and African Studies 12/2: 333-339.

Bunker, Emmy C. 1964. "The Spirit Kings in Sixth-Century Chinese Buddhist Sculpture." Archives of the Chinese Art Society of America 18: 26-37.

Buswell, Robert, ed. 2004. Encyclopedia of Buddhism. 2 volumes. New York: Macmillan Reference USA. 
Carter, Martha L. 1990. The Mystery of the Udayana Buddha. Naples: Instituto Universitario Orientale.

Chandra, Lokesh. 1993. Cultural Horizons of India. 6 volumes. New Delhi: South Asia Books.

-_- 2006. "Suvarna-Bhasottama and the Defence of Serindic Khotan." Paper presented at the "2006 nián xìyù wénxiàn zuòtánhuì 2006 年西域文献座谈会" [Symposium on Texts of the Western Regions, 2006], Běijīng National Library.

Chang Qing. 2010: “Indigenizing Deities: The Budai Maitreya and the Group of Eighteen Luohans in Niche No. 68 at Feilaifeng." Southeast Review of Asian Studies 32: 22-47.

Chappell, David. 2004. "Repentance and Confession." In Buswell 2004, 721-723.

Charleux, Isabelle. 2009. “From North India to Buryatia: The 'Sandalwood Buddha' from the Mongols' Perspective." Paper presented at The Fourth International Conference on Tibetan Archaeology \& Arts (ICTAA IV), Běijīng, October 17-20.

———. 2011. “Cóng Yìndù dào Bùlǐyàtè : Ménggǔrén shìyě zhōng de zhāntán fóxiàng 从北印度到布里亚特: 蒙古人视野中的斿檀佛像 [From North India to Buryatia: The 'Sandalwood Buddha' from the Mongols' perspective]." Palace Museum Journal [Gùgōng bówùyuàn yuànkān 故宮博物院院刊] 2/154: 81-99.

Cartelli, Mary Anne. 2012. The Five-Colored Clouds of Mount Wutai: Poems from Dunhuang. Leiden: Brill.

Chén Huáiyǔ 陳懷宇. 2008. “Dūnhuáng Pelliot 2058V wénshū zhōng de Jié dà Suí qiú tán fā yuànwén 敦煌Pelliot 2058V文書中的《結大隨求 壇發願文》." Dūnhuángxué 敦煌學 27: 167-185. 
Chéng Jùfū 程鋸夫. 1986. “Zhāntán fóxiàng jì 旃檀佛像記 [Record of the Sandal Wood Statue]." In Xuělóu jí 雪樓集, ed. in Sìkù quánshū 四 庫全書 fasc. 1202. Táiběi: Táiwān Shāngwù Yìnshūguăn 台灣商務 印書館.

Coomaraswamy, Ananda K. 1993. Essays on the Water Cosmology. New edition by Paul Schroeder. New Delhi: IGNCA/Oxford University Press.

Davidson, Ronald M. 2002. “Hidden Realms and Pure Abodes: Central Asian Buddhism as Frontier Religion in the Literature of India, Nepal, and Tibet." Pacific World-Journal of the Institute of Buddhist Studies 4: 153-182.

Davis, Richard H. 1997. Lives of Indian Images. Princeton: Princeton University Press.

_- - ed. 1998. Images, Miracles, and Authority in Asian Religious Traditions. Boulder (CO): Westview Press.

DDB: Digital Dictionary of Buddhism (general editor: Charles Muller): http://www.buddhism-dict.net/ddb/.

Deeg, Max. 2005. Das Gaoseng-Faxian-Zhuan als religionsgeschichtliche Quelle. Der älteste Bericht eines chinesischen buddhistischen Pilgermönchs über seine Reise nach Indien mit Übersetzung des Textes. Wiesbaden: Harrassowitz.

-_- 2016. Miscellanae Nepalicae: Early Chinese Reports on NepalThe Foundation Legend of Nepal in its Trans-Himalayan Context. Lumbini: Lumbini International Research Institute.

Dīng Fúbǎo 丁福保. 1984. [1925] Fóxué dàcídiǎn 佛學大辭典 [Encyclopedic Dictionary of Buddhism]. Běijīng: Wénwù Chūbǎnshè 文物出版社. Duàn Qīng 段晴. 2013. Yútián - fójiào - gǔjuàn 于阗 - 佛教-古卷 [Khotan - Buddhism - Ancient texts]. Shànghăi: Zhōngxī shūjú 中西書局. 
Dudbridge, G., and R.E. Emmerick. 1978. "Pelliot tibétain 0821." Studia Iranica 7/2: 283-285.

Dūnhuáng Academy (Dūnhuáng yánjiū yuàn 敦煌研究院), ed. 1996. Dūnhuáng shíkū nèiróng zǒnglù 敦煌石窟內容總錄 [A catalogue of the contents of the Dūnhuáng Caves]. Běijīng: Wénwù chūbǎnshè 文物出版社.

Dūnhuáng yánjiūyuàn 敦煌研究院, ed. 1998. Dūnhuáng shíkū yìshù 敦煌 石窟藝術 [The art of the Dūnhuáng Caves]. 22 volumes. Jiāngsū 江蘇: Jiāngsū měishù chūbănshè 江蘇美術出版社.

Durkin-Meisterernst, Desmond, et. al., eds. 2004. Turfan Revisited: The First Century of Research into the Arts and Cultures of the Silk Road. Monographien zur indischen Archäologie, Kunst und Philologie. Band 17. Berlin: Dietrich Reimer Verlag.

Emmerick, R.E. 1967. Tibetan Texts Concerning Khotan. London, Oxford University Press.

- - , trans. 1992. The Sütra of Golden Light, Being a Translation of the Suvarṇa-prabhāsottama-sūtra. $2^{\text {nd }}$ edition. Oxford: Pāli Text Society.

Filigenzi, Anna, and Mauro Maggi. 2008. "Pelliot Tibétain 2222: a Dunhuang Painting with a Khotanese Inscription." Journal of Inner Asian Art and Archaeology 3: 83-108.

Forte, Antonino. 2005. Political Propaganda and Ideology in China at the End of the Seventh Century. Napoli: Instituto Universitario Orientale Seminario di Studi Asiatici. 
Forte, Erika. 2014. “On a Wall Painting from Topolukdong Site no. 1 in Domoko: New Evidence of Vaisravana in Khotan?" In Changing Forms and Cultural Identity: Religious and Secular Iconographies. Papers from the $20^{\text {th }}$ Conference of the European Association for South Asian Archaeology and Art. Volume 1, edited by Deborah Klimburg-Salter, and Linda Lojda, 215-224. Turnhout: Brepols.

Fraser, Sarah E. 2004. Performing the Visual: the Practice of Buddhist Wall Painting in China and Central Asia, 618-960. Stanford: Stanford University Press.

Galambos, Imre. 2009. "Manuscript Copies of Stone Inscriptions in the Dunhuang Corpus: Issues of Dating and Provenance." AS/EA LXIII/4: 619-636.

Gāo Yǒngjiǔ 高永久, and Wáng Guóhuá 王国华. 1991. “Tǔbō tŏngzhì-xià de Yútiān 吐蕃统治下的于阗 [Khotan under the rule of Tibet]." Xībĕi mínzú yánjiū 西北民族研究 2.

Granoff, Phyllis. 1970. “Tobatsu Bishamon: Three Japanese Statues in the United States and an Outline of the Rise of This Cult in East Asia." East and West 20, no.1/2: 144-168.

Gummer, Natalie D. 2004. Suvarṇaprabhāsottama-sūtra. In Buswell $2004,812$.

Hansen, Valerie. 2005: "The Tribute Trade with Khotan in Light of Materials Found at the Dunhuang Library Cave." Bulletin of the Asia Institute 19 (special issue: Iranian and Zoroastrian Studies in Honor of Prods Oktor Skjærvø, edited by Carol Altman Bromberg, Nicholas Sims-Williams, Ursula Sims-Williams): 37-46. 
Hida Romi. 2006. Ajia chiki bunkagaku no kōsaku アジア地域文化学の構 築—21seki COE programu kenkyū shūsei 21世紀COEプログラム研 究集成. In Ajia chiki bunkagaku sōsho アジア地域文化学猺書, ed. by Waseda daigaku Ajia chiki bunka enhanshingu kenkyū sentā 早 稲田大学アジア地域文化エンハンシング研究センター. Yuzankaku 雄山閣.

Hirakawa Akira 平川彰. 1997. Bukkyō kan-bon dai jiten 佛教漢梵大辭典 [Buddhist Chinese-Sanskrit Dictionary]. Tōkyō: Reiyūkai 霊友会. Jiǎng Jiāhuá 蒋家花. 2016. Zhōngguó fójiào ruìxiàng chóngbài yánjiū 中国 佛教瑞像崇拜研究 [Studies in the Auspicious Images Cult in China]. Jìnán: Qílŭ shūshè 齐鲁书社.

Jīn Shēn. 2005. “Hàn Zàng fójiào zhōng de zhāntán ruìxiàng 汉藏佛教中 的旃檀瑞像 [Sandalwood Auspicious Statues in the Chinese and Tibetan Buddhism]." Wénwù chūnqiū 文物春秋 4: 31-40.

Joo, Bong Seok. 2007. "The Arhat Cult in China from the Seventh Through the Thirteenth Centuries: Narrative, Art, Space and Ritual." PhD diss., Princeton University.

Klimburg-Salter, D.E. 1981. Vaiśravaṇa in North-West India. In MADHU: Recent Researches in Indian Archaeology and Art History. Shri M.N. Deshpande Felicitation Volume, edited by M.S.N. Rao, 253262. Delhi.

Kudara Kōgi. 2004: Uigur and Tibetan Translations of The History of the Buddha Statue of Sandalwood in China. In Durkin-Meisterernst, et. al. 2004, 149-154.

Kumamoto Hiroshi. 1991. "Some Khotanese Letters in Verse." Tokyo University Linguistics Papers 12: 59-80.

- - . 1996. "The Khotanese in Dunhuang." In Cina e Iran: Da Alessandro Magno alla Dinastia Tang, edited by Alfredo Cadonna, and Lionello Lanciotti, 79-101. Orientalia Venetiana 5. Florence: Leo S Olschiki Editore. 
_-_. 1999. "Textual Sources for Buddhism in Khotan." In Buddhism Across Boundaries - Chinese Buddhism and the Western Regions, edited by J. Nattier, and J. McRae, 345-360. Sanchung.

_-_. 2009: "Khotan. History in the Pre-Islamic Period." In Encyclopedia Iranica Online. www.iranica.com.

_-_. 2012. "Textual Sources for Buddhism in Khotan." In Buddhism Across Boundaries, edited by John McRae, and Jan Nattier. SinoPlatonic Papers 222: 142-149.

Lévi, Sylvain. 1905. “Notes chinoises sur I'Inde V. Quelques documents sur le bouddhisme indien dans l'Asie centrale (première partie)." Bulletin de l'École Francaise d'Extreme Orient 5/3-4: 253-305.

Liú Guóruì 刘国瑞, Qū Tāo 屈涛, and Zhāng Yùzhōng 张玉忠. 2005: “Xīnjiāng Dāndān-Wūly̌kè yízhǐ xīn fāxiàn de fósì bìhuà 新疆丹丹乌 里克遗址新发现的佛寺壁画 [Newly discovered Buddhist temple wall paintings from Dandan-Uiliq]." Xīyù yánjiū 西域研究 4: 52-60.

Liú Yīng 刘颖. 2010. “Dūnhuáng Mògāo-kū Tǔbō hòuqī jīngbiànhuà yánjiū 敦煌莫高窟吐蕃后期经变画研究 [Studies in the Transformation Tableaux of the Mògāo Caves during the period after the Tibetan period of Dūnhuáng]." PhD thesis, Zhōngyāng měishù xuéyuàn 中央美術學院.

Mă Xīnguăng 马新广. 2012. “Táng Wŭ-dài fósì bìhuà de wénxiàn kăochá 唐五代佛寺壁画的文献考察 [An investigation of literary works concerning the wall paintings of monasteries of the Táng and Five Dynasties periods]." Bĕijīng: Zhōngguó shèhuì kēxué chūbănshè 中國社會科學出版社.

Maggi, Mauro. 2009. "Khotanese Literature." In The Literature of pre-Islamic Iran: Companion Volume I to A History of Persian Literature, edited by Ronald E. Emmerick, and Maria Macuch, 330-417. London. 
Mair, Victor, and Prods Oktor Skjærvø. 2011. “Chinese Turkestan ii. In PreIslamic Times." Encyclopeadia Iranica, http://www.iranicaonline. org/articles/chinese-turkestan-ii, accessed September 2013.

Mair, Victor. 2012. "The Khotanese Antecedents of The Sūtra of the Wise and the Foolish (Xianyu jing)." In Buddhism Across Boundaries, edited by John McRae, and Jan Nattier, 150-178. Sino-Platonic Papers 222.

McCallum, Donald F. 1998. "The Replication of Miraculous Images: the Zenkoji Amida and the Seryoji Shaka." In Images, Miracles, and Authority in Asian Religious Traditions, edited by Richard $\mathrm{H}$. Davis, 207-226. Boulder: Westview Press.

McNair 1994. "Sandalwood Auspicious Image." In Latter Days of the Law: Images of Chinese Buddhism: 850-1850, edited by Marsha Smith Weidner, and Patricia Ann Berger. Honolulu: University of Hawai'i Press.

Neelis, Jason. 2012. "Overland Shortcuts for the Transmission of Buddhism." In Highways, Byways, and Road Systems in the Pre-Modern World, edited by Susan E. Alcock, John Bodel, and Richard J.A. Talbert, 12-32. Hoboken (NJ): John Wiley \& Sons.

Ning Qiang. 1999. “Diplomatic Icons: Social and Political Meanings of Khotanese Images in Dunhuang Cave 220." Oriental Art 44/4: 2-15.

- - . 2004. Art, Religion, and Politics in Medieval China: the Dunhuang Cave of the Zhai Family. Honolulu: University of Hawai'i Press.

Nobel, Johannes, ed. 1937. Suvarnabhasottamasutra. Leipzig: Otto Harrassowitz.

Peri, Noel. 1917. “Hariti: La Mere-de-Demons.” BEFEO 17/3: 1-102.

Pons, Jessie. 2014. The Figure with a Bow in Gandhāran Great Departure Scenes. Some New Readings. Entangled Religions 1: 15-94. 
Rong Xinjiang. 2013. Eighteen Lectures on Dunhuang. Translated by Imre Galambos. Leiden: Brill.

Róng Xīnjiāng 荣新江, Zhū Lìshuāng 朱丽双. 2013. Yútián yŭ Dūnhuáng 于阗与敦煌 [Khotan and Dūnhuáng]. Lánzhōu 兰州: Gānsù jiàoyù chūbănshè 甘肅教育出版社.

Schmid, Neil. 2006. "The Material Culture of Exegesis and Liturgy and a Change in the Artistic Representations in Dunhuang Caves, ca. 700-1000." Asia Major 14 (Special Issue: Essays in Honor of Professor Victor H. Mair, ed. by Daniel Boucher, Neil Schmid, and Tansen Sen): 171-210.

van Schaik, Sam. 2013. “Red Faced Barbarians, Benign Despots and Drunken Masters: Khotan as a Mirror to Tibet." Pre-publication draft (cited according to the paper at: https://bl. academia.edu/ SamvanSchaik).

Shā Wǔtián 沙武田. 2006. “Dūnhuáng shíkū Yútián guówáng huàxiàng yánjiū 敦煌石窟于阗国王画像研究 [Studies in the images of the King of Khotan at the Dūnhuáng caves]." Xīnjiāng shīfàn dàxué xuébào 新疆师范大学学报 27/4: 22-30.

Sharf, Robert H., and Elizabeth H. Sharf. 2001: Living Images: Japanese Buddhist Icons in Context. Asian Religions and Cultures Series. Palo Alto: Stanford University Press.

Skjærvø, Prods Oktor. 2004. This Most Excellent Shine of Gold, King of Kings of Sutras: the Khotanese Suvarnabhāsottamasūtra. 2 volumes. Cambridge, Mass.: Cambridge University Press.

_-_. 2012. "Khotan, an Early Center of Buddhism in Chinese Turkestan." In Buddhism Across Boundaries, edited by John McRae, and Jan Nattier. Sino-Platonic Papers 222: 106-141.

Soper, Alexander. 1959. Literary Evidence for Early Buddhist Art in China. Ascona: Artibus Asiae. (Artibus Asiae Supplementum XIX). 
Soymiè, M. 1984. “Quelques représentations de statues miraculeuses dans les grottes de Touen-houang." In Contributions aux études de Touen-houang. Volume 3, 77-102. Paris: Ecole française d'Extrême-Orient.

Stein, M. Aurel. 1907. Ancient Khotan. Oxford: Clarendon Press.

Sūn Xiūshēn 孙修身. 1986. “Dūnhuáng fójiào yìshù hé gŭdài Yútián 敦煌佛 教艺术和古代于阗 [Buddhist art at Dūnhuáng and ancient Khotan]." Xīnjiāng shèhuì kēxué 新疆社会科学: 1 .

—- - 2000. Dūnhuáng fójiào dōngzhuàn gùshìhuà juàn 敦煌佛教东传故事 画卷 [Volume on the narrative iconography of the transmission of Buddhism to the East]. Shíkū quánjí 石窟全集 [Complete collection on rock caves] 12. Shànghǎi: Shànghǎi rénmín chūbǎnshè 上海 人民出版社.

[T.:] Takakusu Junjirō, ed. 1922-1933. Taishō shinshū daizōkyô 大正新修 大藏經 [Revised Edition of the Buddhist Canon in the Taishō-era]. 100 volumes. Tōkyō, Daizō shuppan kai 大藏出板會. [Searches in the $\mathrm{T}$. according to CBETA]

Takata, Tokio. 2000. “Multilingualism in Tun-huang." Acta Asiatica 78: 49-70. [Page number references in this paper according to a digitized draft version of the article]

Tanabe Katsumi 田辺勝美. 2006. Bishamonten zō no kigen 毘沙門天像 の起源 [The origin of the Vaiśravaṇa image]. Tōkyō: Sankibō butsushorin 山喜房仏書林.

Terentyev, Andrey. 2010. The Sandalwood Buddha of the King Udayana: Sandalovy Budda raji Udayany. Saint-Pétersbourg: Nartang.

Thomas, F.W. 1935. Tibetan Literary Texts and Documents Concerning Chinese Turkestan. Part I: Literary Texts. London: Royal Asiatic Society. 
Tsiang, Katherine R. 1996. “Monumentalization of Buddhist Texts in the Northern Qi Dynasty: The Engraving of Sutras in Stone at the Xiangtangshan Caves and Other Sites in the Sixth Century." Artibus Asiae 56 no.3/4: 233-261.

Uray, G. 1979. The Old Tibetan Sources of the History of Central Asia up to 751 A.D.: A Survey. In Prolegomena to the Sources on the History of Pre-Islamic Central Asia, edited by J. Harmatta, 275304. Budapest: Akadémiai Kiadó.

Wáng Jiāpéng 王家鵬. 2005. “Dìwáng yǔ zhāntán ruìxiàng 帝王與斿檀瑞像 [The Emperor and the Sandal Wood Statue]." Zijjìnchéng 紫禁城 [Forbidden City] 128 (1): 178-187.

Warner, Cameron D. 2008. “The Precious Lord: The History and Practice of the Cult of the Jowo Shākyamuni Statue in Lhasa, Tibet." PhD diss., Harvard University, Cambridge (MA).

Wenzel, Claudia. 2011. "The Image of the Buddha: Buddha Icons and Aniconic Traditions in India and China." Transcultural Studies 1: 263-305.

William, J. 1973. "The Iconography of Khotanese Paintings." East and West 23, 1/2: 109-154.

Wu Hung. 1992. "What is Bianxiang? On the Relationship Between Dunhuang Art and Dunhuang Literature." Harvard Journal of Asiatic Studies 52, 1: 111-192.

_- - 1996. “Rethinking Liu Sahe: The Creation of a Buddhist Saint and the Invention of a 'Miraculous Image'." Orientations 27/10: 32-43.

Wū Xīnhuá 巫新华. 2009. “Xīnjiāng Hétiān Dámăgōu fósì kăogǔ xīn fāxiàn yǔ yánjiū 新疆和田达玛沟佛寺考古新发现与研究 [New discoveries and research on Buddhist temples in Dámăgōu village, Xīnjiāng]." Wénwù 文物 8: 55-68. 
Yamazaki Gen'ichi. 1990. “The Legend of the Foundation of Khotan." Memoirs of the Research Department of the Toyo Bunko 47: 5580.

Zhāng Guǎngdá 张广达 and Róng Xīnjiāng 荣新江. 1986. “Dūnhuáng 'ruìxiàng jì', ruìxiàng tú jí fănyìng de Yútián 敦煌瑞像记, 瑞像图及其 反映的于阗 [The records and pictures of Auspicious Statues and the Khotan they reflect]." In Dūnhuáng Tŭlǔfān wénxiàn yánjiū lùnji 敦煌吐鲁番文献研究论集 3. Běijīng: Běijīng dàxué chūbănshè 北京大学出版社.

Zhāng Xiǎogāng 张小刚. 2005. “Dūnhuáng ruìxiàngtú-zhōng de Yútián hùguó shénwáng 敦煌瑞像图中的于阗护国神王 [Protective deities of Khotan among the Auspicious Statues depictions in Dūnhuáng]." Dūnhuáng yánjiū 敦煌研究 1 (89): 50-56.

——- 2008. “Dūnhuáng suǒjiàn Yútián Niútóu-shān shèngji jí ruìxiàng 敦 煌所见于阗牛头山圣迹及瑞像 [Relics and Auspicious Statues depicted in Dūnhuáng concerning Mt. Niútóu in Khotan]." Dūnhuáng yánjiū 敦煌研究 4 (110): 6-11 (with illustrations on pp. 116-117).

_-_. 2012. “Dūnhuáng găntōng gùshìhuà băngtí chăolùgăo yánjiū 敦煌 感通故事画榜题抄录稿研究 [Studies in the manuscript copies of the captions of miraculous narratives depictions of Dūnhuáng]." In Qìnghè Ráo Zōngyí xiānshēng jiǔ-shí-wǔ huádàn Dūnhuángxué guójì xuéshù yánlùnhuì lùnwénjí 庆贺饶宗臨先生九十五华诞敦煌学国 际学术研讨会论文集 [Collection of articles from the international conference on Dūnhuáng studies on the occasion of Professor Ráo Zōngyí's 95 th Birthday], edited by the Dūnhuáng Academy, 404-423. Běijīng: Zhōnghuá shūjú 中华书局.

—-—. 2015. Dūnhuáng fójiào găntōnghuà yánjiū 敦煌佛教感通畫研究 [A study of Buddhist miraculous images in Dūnhuáng]. Lánzhōu: Gānsù jiàoyù chūbănshè 甘肃教育出版社. 
Zhāng Yāshā 张亚莎. 1999. “Tǔbō yŭ Yútián guānxì kăo 吐蕃与于阗余系考 [Studies in the relationship between Tibet and Khotan]." Xīzàng yánjiū 西藏研究: 1.

Zhang Yuzhong, Qu Tao, and Liu Guorui. 2008. “A Newly Discovered Buddhist Temple and Wall Paintings at Dandan-Uiliq." Journal of Inner Asian Art and Archaeology 3: 157-170.

Zhèng Bǐnglín 郑炳林. 1997. Dūnhuáng Guīyì jūn shǐ zhuāntí yánjiū 敦 煌归义军史专题研究 [A monographic study of the history of the ‘Return to Righteousness' Army]. Lánzhōu 兰州: Lánzhōu dàxué chūbănshè 兰州大学出版社.

———. 2003. Dūnhuáng Guīyì jūn shǐ zhuāntí yánjiū xùbiān 敦煌归义军史专 题研究续编 [Continuation of the monographic study of the history of the ‘Return to Righteousness' Army]. Lánzhōu 兰州: Lánzhōu dàxué chūbănshè 兰州大学出版社.

[Zhōnguó shíkū, Dūnhuáng] Dūnhuáng wénwù yánjiūsuǒ 敦煌文物研究所, ed. (1984) 1999. Zhōngguó shíkū: Dūnhuáng Mògāo kū 中國石窟: 敦煌莫高窟 [Chinese rock caves: the Dūnhuáng Mògāo Caves]. 5 volumes. Běijīng/Tōkyō: Wénwù chūbǎnshè 文物出版社.

Zieme, Peter. 2006. Magische Texte des uigurischen Buddhismus. Berliner Turfantexte XXIII. Turnhout (Belgium)/Washington DC: Brepols Publishers.

Zürcher, Erik. (1959) 1972. The Buddhist Conquest of China-The Spread and Adaptation of Buddhism in Early Medieval China. 2 volumes. Leiden: Brill. 